\title{
Fossil wood flora from the Siwalik Group of Arunachal Pradesh, India and its climatic and phytogeographic significance
}

\author{
Gaurav Srivastava $^{1}$, R C Mehrotra ${ }^{1, *}$ and C Srikarni ${ }^{2}$ \\ ${ }^{1}$ Birbal Sahni Institute of Palaeosciences, 53 University Road, Lucknow 226 007, India. \\ ${ }^{2}$ Geological Survey of India, Sector 10A, Gandhinagar 282 010, India. \\ *Corresponding author. e-mail: rcmehrotra@yahoo.com
}

MS received 17 January 2017; revised 23 June 2017; accepted 3 July 2017; published online 10 February 2018

The plant fossil records from the Siwalik Group of Arunachal Pradesh, India are far from satisfactory due to remoteness and dense vegetation of the area. We report seven fossil woods of which three belong to the Middle Siwalik (Subansiri Formation), while the rest are from the Upper Siwalik (Kimin Formation). The modern analogues of the fossils from the Middle Siwalik are Lophopetalum littorale (Celastraceae), Afzelia-Intsia and Sindora siamensis (Fabaceae) and from the Upper Siwalik are Miliusa velutina (Annonaceae), Calophyllum tomentosum and Kayea (Calophyllaceae) and Diospyros melanoxylon (Ebenaceae). The dominance of diffuse porosity in the fossil woods indicates a tropical climate with low seasonality (little variation) in temperature, while a high proportion of large vessels and simple perforation plates in the assemblage infer high precipitation during the deposition of the sediments. The aforesaid inference is in strong agreement with the previous quantitative reconstruction based on fossil leaves. Several modern analogues of the fossil taxa are now growing in low latitudes possibly due to an increase in seasonality (increased variation) in temperature caused by the rising Himalaya.

Keywords. Megaflora; systematics; Neogene; northeast India; palaeoclimate.

\section{Introduction}

The Siwalik denotes low elevation (varying from a few hundred metres to $\sim 1200 \mathrm{~m}$ ) mountain ranges formed in between the lesser Himalaya (in the north) and the Gangetic Plains (in the south), due to the rising Himalaya since the middle Miocene (Karunakaran 1974). It extends all along the Himalayan foot-hills covering a distance of $\sim 2400 \mathrm{~km}$ from Sindh of Pakistan in the west to Assam in the east attaining a width of $20-25 \mathrm{~km}$. The Siwalik sediments were deposited in a fluvial environment, in coarsing-upward succession and are divided into three subgroups, namely Lower, Middle and Upper Siwalik (Pilgrim 1910; Johnson et al. 1985; Ranga Rao et al. 1988; Valdiya 2002).

The flora archived in the Siwalik Group is very important for the study of vegetation in relation to climate change that occurred due to the rising Himalaya since the middle Miocene (Prasad 2008; Khan et al. 2014a). The fossil flora discovered from the Himalayan foreland basin is predominantly based on leaves and fruits, while the wood flora is still very meagre (Prasad 2008; Srivastava et al. 2014). Most of the fossils recovered from the Siwalik Group are from the foot-hills of 
northwest Himalayan region (Prasad 2006; Shashi et al. 2006, 2008); however, from northeastern Himalayan region the fossil data is still far from satisfactory because of the remoteness of the area (Srivastava et al. 2014). In view of the aforesaid reasons, it is important to discover more fossils from the Siwalik of northeastern part of India to study the vegetation vis-à-vis climate change caused due to the rising Himalaya. A comparative study of northeastern and western parts of the Siwalik flora would be very useful for the study of evolution of continental climate caused by the upheaval of Himalaya. In northeastern region (NER), the Siwalik sediments (Lower, Middle and Upper) are exposed in Arunachal Pradesh (ARP), where floristic assemblage is predominantly based on leaves and fruits (Singh and Prakash 1980; Joshi and Mehrotra 2003, 2007; Joshi et al. 2003a,b; Bera et al. 2004, 2014; Khan and Bera 2007, 2010, 2014, 2016, 2017; Khan et al. 2008, 2009, 2011, 2014b, 2015, 2016, 2017; Bera and Khan 2009; Srivastava and Mehrotra 2009) with a meagre wood flora (Mehrotra et al. 1999; Joshi et al. 2003b). The dominant families are Calophyllaceae, Combretaceae, Dipterocarpaceae, Fabaceae and Lauraceae.

In the present communication, we report seven fossil woods from the Middle and Upper Siwalik sediments of Arunachal Pradesh (figures 1a, 3).

\section{Regional geology}

In NER, Arunachal Pradesh (ARP) has the largest land area and is bounded by countries like China in the north, Bhutan in the west and Myanmar in the east. About $80 \%$ of the geographical area of $\mathrm{ARP}$ is covered by lush green vegetation. In ARP, the Siwalik is exposed as a linear belt along the foot-hills whose northern part is limited by Main Boundary Fault (MBF) from the overlying Gondwana rocks, while the southern part is trammeled by Main Frontal Fault (MFF) from the underlying alluvium deposits. In ARP, the Siwalik is classified into three formations such as Dafla (middle-late Miocene), Subansiri (Pliocene) and Kimin (late Pliocene-early Pleistocene) which are equivalent to Lower, Middle and Upper Siwalik sub-divisions of northwestern Himalaya (Karunakaran and Ranga Rao 1979). These three sub-divisions are separated from each other by reverse faults and are arranged in reverse stratigraphic order (table 1) (Kumar 1997; Joshi and Chakraborty 2001). The magnetostratigraphic study of the Siwalik sediments from West Kameng district suggests that these sediments were deposited between 13 and 2.5 Ma and the changeover from Lower to Middle Siwalik occurred at $\sim 10.5 \mathrm{Ma}$, while that from Middle to Upper Siwalik took place at $\sim 2.6 \mathrm{Ma}$ (Chirouze et al. 2012). Lithologically, the Lower Siwalik consists of an alternation of fine- to medium-grained sandstones and variegated mudstones which were deposited by a meandering river, while the Middle Siwalik is of medium- to coarse-grained, grey, micarich salt-and-pepper coloured sandstones which were deposited by a braided river (Tandon 1991). The Upper Siwalik comprises pebble and cobble conglomerates formed as alluvial fan deposits near the mountain front.

The sediments of Dafla Formation (Lower Siwalik) consist of indurated, medium- to fine-grained, well sorted, bluish-grey sandstone and bluish-grey, greenish-grey, and nodular silty shale. Stringers and small lenses of lignitic coal aligned parallel to the bedding plane are frequent. In the Lower Siwalik, bed forms are laminated to massive, large trough, festoon, planar curved, and tabular cross beds together with ripple cross laminations (Joshi and Chakraborty 2001). The Subansiri Formation (Middle Siwalik) named after the Subansiri River (Karunakaran and Ranga Rao 1979) is gradationally underlain by the Dafla Formation and overlain by the Kimin Formation. Lithologically, it is characterized by the presence of salt-andpepper coloured, coarse- to medium-grained grey micaceous, soft, thick bedded massive sandstones (figures 2, 3d) and represents the valley filled deposits frequented by ephemeral streams. Total cumulative thickness of the Subansiri Formation is $\sim 4200 \mathrm{~m}$ (Raju and Misra 2009) of which upper $\sim 650 \mathrm{~m}$ is exposed in the study area. Moreover, the Kimin Formation (Upper Siwalik) whose composite thickness is $\sim 2300 \mathrm{~m}$, is gradationally underlain by the Subansiri Formation and unconformabily overlain by the alluvium deposits. The lithology is mainly represented by loosely packed, very coarse to fine-grained, friable, grey sandstone which is highly limonitised at places (figure 2 ; table 1 ).

\section{Materials and methods}

Several fossil wood samples were collected from the areas having the exposures of Middle and Upper Siwalik (figures 1,3). The wood pieces were sampled from the large trunks embedded in the section with the help of a chisel and hammer. All 


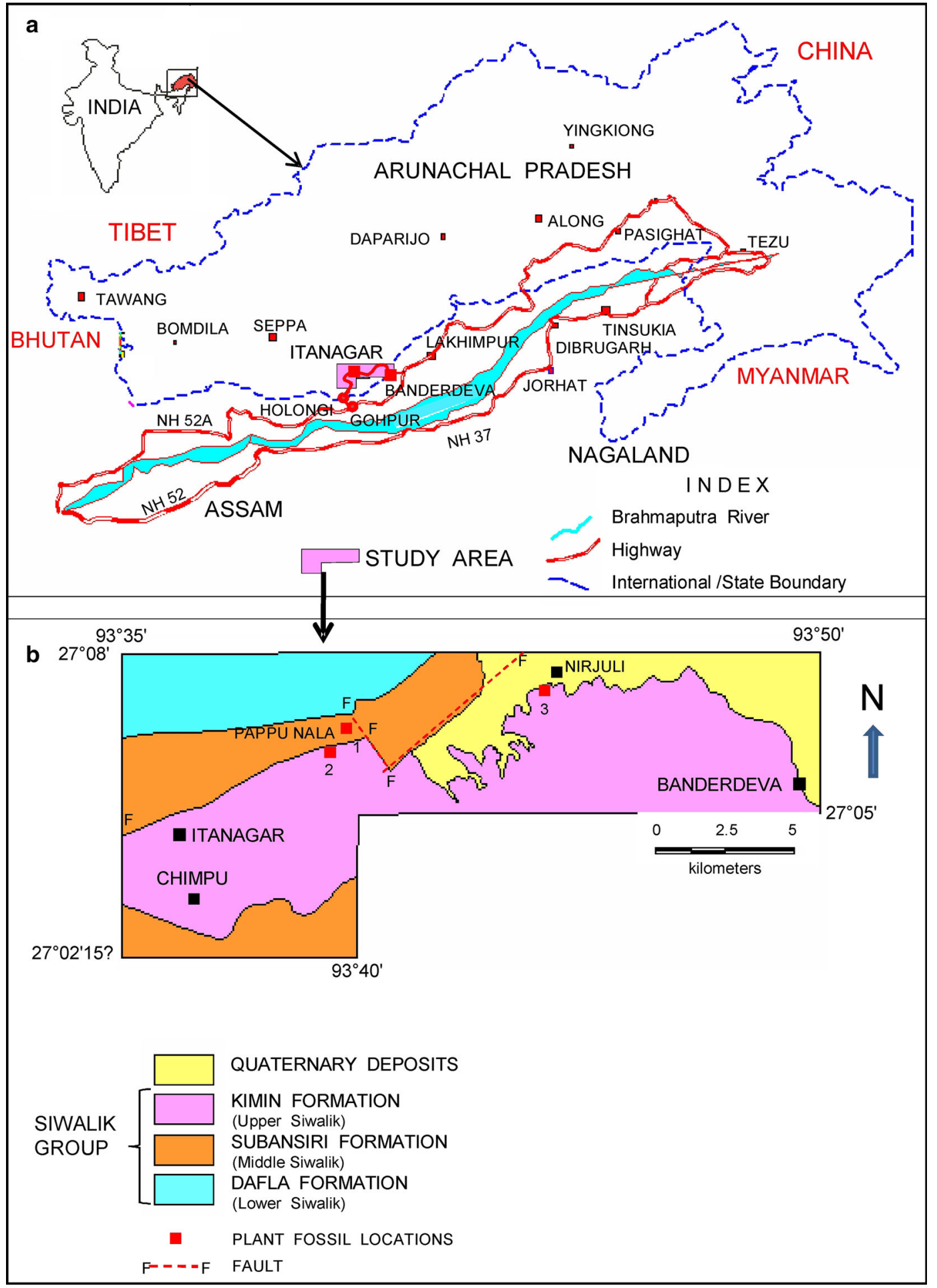

Figure 1. (a) Map showing the study area. (b) Generalized geological map of the study area (1. Pappu Nala, 2. Near $7 \mathrm{~km}$ post on the Itanagar-Banderdeva road, 3. One km before Nirjuli on the Nirjuli-Banderdeva road).

the unearthed fossil wood samples were sectioned transversally and longitudinally (i.e., radially and tangentially). The standard method of grinding and polishing with different grades of carborundum powder was used during slide preparation and finally mounted in Canada balsam (Lacey 1963).
All type of slides are housed in the museum of the Birbal Sahni Institute of Palaeosciences, Lucknow (India). The slides were examined under transmitted light microscope. Total seven fossil woods are described from the Middle and Upper Siwalik sediments of Arunachal Pradesh. Of them, 
Table 1. Generalised litho-tectonic succession in Arunachal Pradesh (after Joshi and Chakraborty 2001).

Gondwana $\begin{gathered}\text { Carbonaceous shale, } \\ \text { sandstone and coal with } \\ \text { plant fossils }\end{gathered}$
Wower Siwalik
Shall indurated sandstone,
abundant plant fossils

three fossil woods belong to the Middle, while four are from the Upper Siwalik sediments. The fossil woods were identified after comparing them with modern woods both from thin sections available at the Birbal Sahni Institute of Palaeosciences, Lucknow (BSIP) and published literature (Pearson and Brown 1932; Metcalfe and Chalk 1950; Kribs 1959; Ilic 1991; http://insidewood.lib.ncsu. $\mathrm{edu} /$ ). We followed the anatomical terms given by Wheeler et al. (1986) and the International Association of Wood Anatomists (1989) while describing the fossil woods (http://insidewood.lib.ncsu.edu/, Gregory et al. 2009).

\section{Systematic description}

\section{Family: Annonaceae}

Genus: Polyalthioxylon Bande (1973)

Polyalthioxylon arunachalensis Srivastava, Mehrotra and Srikarni, sp. nov.

(figure $4 \mathrm{a}-\mathrm{e}$ )

Specific diagnosis: Wood diffuse porous. Vessels round to oval, mostly small to medium, solitary and in radial pairs, evenly distributed; perforations simple. Axial parenchyma uniseriate, closely spaced scalariform bands. Rays 1-6 seriate, uniseriates rare; ray tissue weakly heterogeneous. Fibres thick walled, non-septate.
Holotype: Specimen no. BSIP41159; figure 4. Type horizon: Upper Siwalik (= Kimin Formation).

Type locality: Near $7 \mathrm{~km}$ post on the ItanagarBanderdeva road.

Age: Late Pliocene-Early Pleistocene.

Etymology: The specific name is after Arunachal Pradesh.

Description: Wood diffuse porous (figure 4a). Growth rings not observed. Vessels round to oval, mostly small, occasionally medium, tangential diameter range 59-118 $\mu \mathrm{m}$ and average about $75 \mu \mathrm{m}$, solitary and in radial pairs, 35-40 per $\mathrm{mm}^{2}$, evenly distributed, filled with dark coloured gummy deposits (figure 4a, b); vessel elements 79-148 $\mu \mathrm{m}$ in length with horizontal to oblique ends; perforations simple. Axial parenchyma apotracheal, uniseriate, closely spaced scalariform bands (figure $4 \mathrm{~b}$ ); cells $31-44 \mu \mathrm{m}$ in length and $28-31 \mu \mathrm{m}$ in width. Rays 1-6 seriate, $15-18$ per $\mathrm{mm}$ (figure 4c, d); uniseriates rare, mostly made up of procumbent cells with 1 or 2 rows of upright or square cells, $5-96 \mu \mathrm{m}$ in width and $132-1557 \mu \mathrm{m}$ in height; ray to ray fusion present; ray tissue weakly heterogeneous, procumbent cells $27-31 \mu \mathrm{m}$ in radial length and $10-19 \mu \mathrm{m}$ in tangential height; upright cells $28-32 \mu \mathrm{m}$ in tangential height and about $20 \mu \mathrm{m}$ in radial length (figure 4e). Fibres polygonal in cross section, thick walled, non-septate.

Affinities: The important structural features of the fossil are: diffuse porous wood, vessels filled with gummy deposits, thin, closely spaced scalariform bands of axial parenchyma, moderately broad and mostly homocellular rays and non-septate fibres which indicate its affinities with Annonaceae (Pearson and Brown 1932; Kribs 1959; Ilic 1991). The other closely allied families are Ebenaceae, Lecythidaceae and Sapotaceae. Ebenaceae can be differentiated from our fossil in having narrower rays, while the other two families are generally characterized by heterocellular rays (Pearson and Brown 1932; Metcalfe and Chalk 1950; Kribs 1959; Ilic 1991). According to Chowdhury and Tandan (1958), most of the genera of the Annonaceae are xylotomically homogeneous and difficult to be distinguished. However, the present fossil shows maximum resemblance with Miliusa Lesch., especially $M$. velutina (Dunal) Hk. f. \& Th. (slide no. BSIP2275).

Kramer (1974) instituted the genus Polyalthioxylon for the fossil woods of Polyalthia Bl., Platymitra 


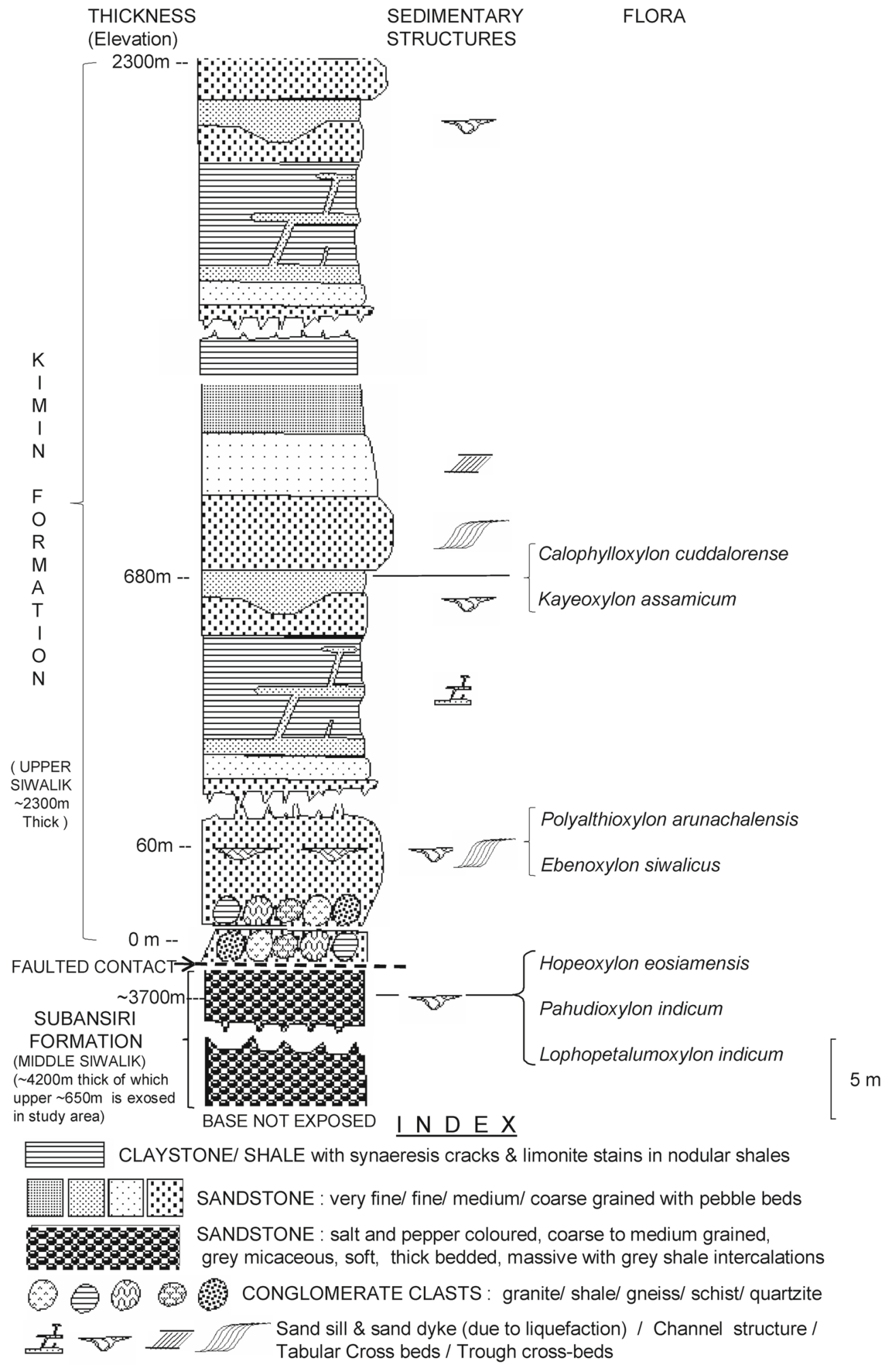

Figure 2. Generalized litholog of the study area.

Boerl., Stelechocarpus Hooker f. \& Thomson and other xylotomically similar taxa. Bande (1973) also established the genus Polyalthioxylon for the fossil woods of Polyalthia only. Prakash (1978) preferred Kramer's genus as most of the genera of the Annonaceae are homogeneous in their wood anatomy. According to the botanical code of nomenclature (Rule 12A), a taxon can bear only one correct epithet, that is, the earliest. Therefore, we have preferred Polyalthioxylon Bande. To date five species of Polyalthioxylon, namely P. indicum Prakash (1978) from the Siwalik of 



Figure 3. (a) Showing an Upper Siwalik locality situated $1 \mathrm{~km}$ before Nirjuli. (b) A Middle Siwalik locality of Pappu Nala showing a fossil wood embedded in sandstone. (c) An Upper Siwalik locality situated at 7 km post on the ItanagarBanderdewa road. (d) A section of the Middle Siwalik locality of Pappu Nala showing salt-and-pepper coloured sandstone.

Uttar Pradesh, P. oldhavenense Crawley (2001) from the Palaeogene of the United Kingdom, $P$. parapaniense Bande (1973) from the Deccan Intertrappean beds of India, P. platymitroides Kramer (1974) and P. stelechocarpoides Kramer (1974) from the Neogene of southeast Asia are known. The present fossil is distinct from all of them in having narrower rays and therefore, is described as Polyalthioxylon arunachalensis sp. nov., the specific name indicating its occurrence in Arunachal Pradesh.

Miliusa comprises small trees and shrubs found in India, southeast Asia and Australia. M. velutina is a tree distributed in the deciduous forest of northern and central India. It is also found in subHimalayan tract from Ganges eastwards, in Assam, Odisha, Andhra Pradesh, Madhya Pradesh and Myanmar (Chowdhury and Tandan 1958).

\section{Family: Calophyllaceae}

Genus: Calophylloxylon Lakhanpal and Awasthi (1965)

Calophylloxylon cuddalorense Lakhanpal and Awasthi (1965)

(figure 5a-f)

Description: Wood diffuse porous (figure 5a). Growth rings absent. Vessels circular to oval, tangential diameter range $52-266 \mu \mathrm{m}$ and average $104 \mu \mathrm{m}$, mostly solitary, arranged in oblique radial lines, 7-11 vessels per $\mathrm{mm}^{2}$, tylosed (figure 5a, b); vessel elements $111-117 \mu \mathrm{m}$ in length with horizontal to oblique ends; perforations simple. Vasicentric tracheids present (figure 5e), pits 3$4 \mu \mathrm{m}$ in diameter, arranged in 1 or 2 rows. Axial parenchyma apotracheal banded, bands mostly continuous, $2-8$ cells wide, band width $46-136 \mu \mathrm{m}$, 

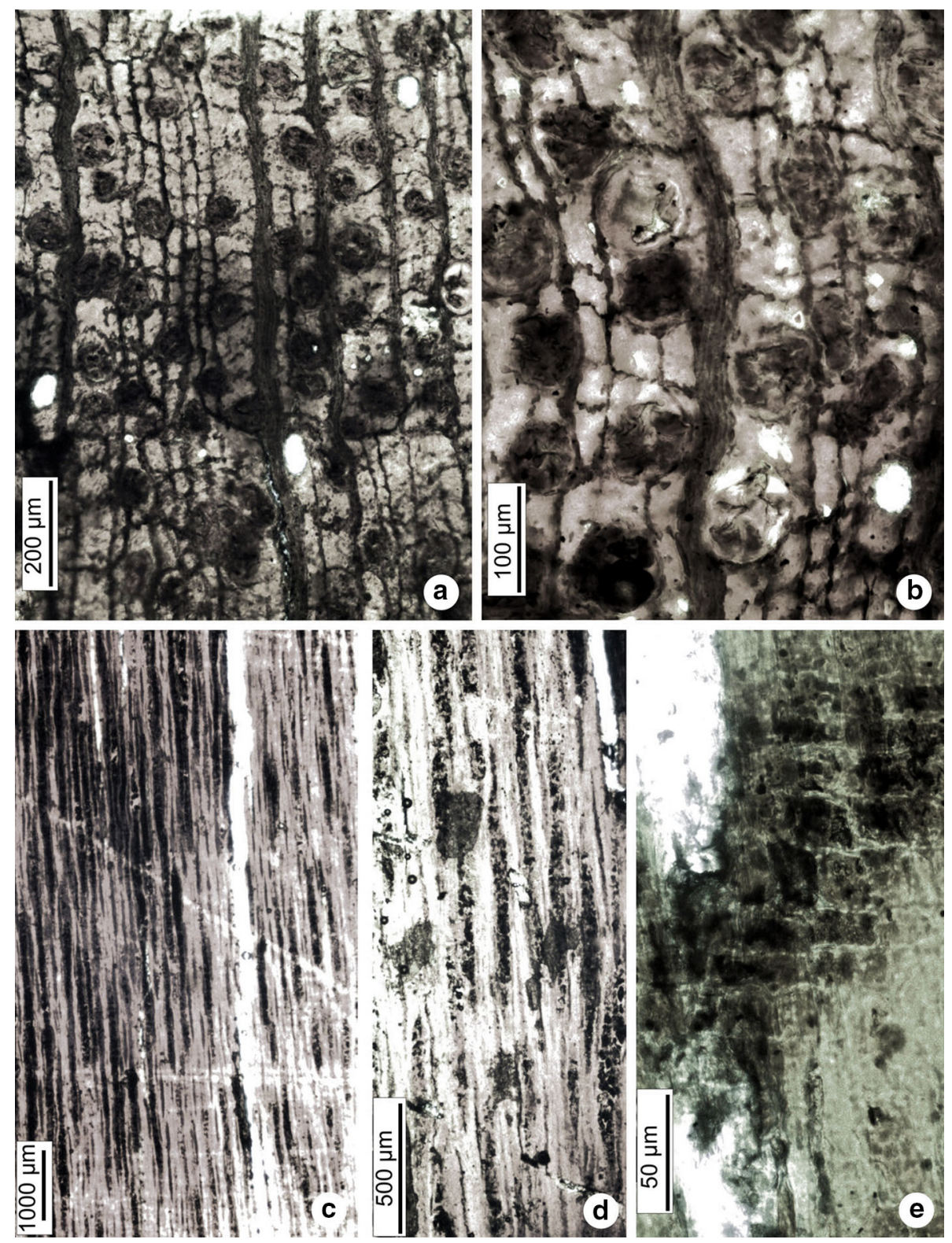

Figure 4. Polyalthioxylon arunachalensis Srivastava et al., sp. nov. (a) Transverse section (Ts) showing shape, size and distribution of vessels. (b) Ts showing closely spaced uniseriate scalariform bands of axial parenchyma. (c) Tangential longitudinal section (Tls) showing distribution of rays. (d) Tls showing structure of rays and non-septate fibres. (e) Radial longitudinal section (Rls) showing weakly heterogeneous ray tissue.

distance between two bands 250-409 $\mu \mathrm{m}$ (figure 5a, b). Rays uniseriate, 2-35 cells or $48-567 \mu \mathrm{m}$ high, width $11-19 \mu \mathrm{m}$ (figure $5 \mathrm{c}, \mathrm{d}$ ); ray tissue weakly heterogeneous, mostly made of procumbent cells with 1 or 2 rows of upright or square cells (figure 5f); procumbent cells $12-18 \mu \mathrm{m}$ in tangential height and $46-58 \mu \mathrm{m}$ in radial length; upright or square cells $44-48 \mu \mathrm{m}$ in tangential height and 40$47 \mu \mathrm{m}$ in radial length (figure $5 \mathrm{f}$ ). Fibres polygonal in cross section, moderately thick walled, nonseptate.

Figured specimen: Specimen no. BSIP41160. Horizon: Upper Siwalik (= Kimin Formation).
Locality: $1 \mathrm{~km}$ before Nirjuli on the NirjuliBanderdeva road.

Age: Late Pliocene-Early Pleistocene.

Affinities: The diagnostic features of the fossil wood, viz., diffuse porous wood, simple perforations, mostly solitary vessels arranged in oblique radial lines, vasicentric tracheids, continuous thick apotracheal bands of axial parenchyma, exclusively uniseriate rays and non-septate fibres indicate its close affinities with Clusiaceae and Parinari Aubl. of the Chrysobalanaceae (Pearson and Brown 1932; Metcalfe and Chalk 1950; Kribs 1959; Miles 1978; 


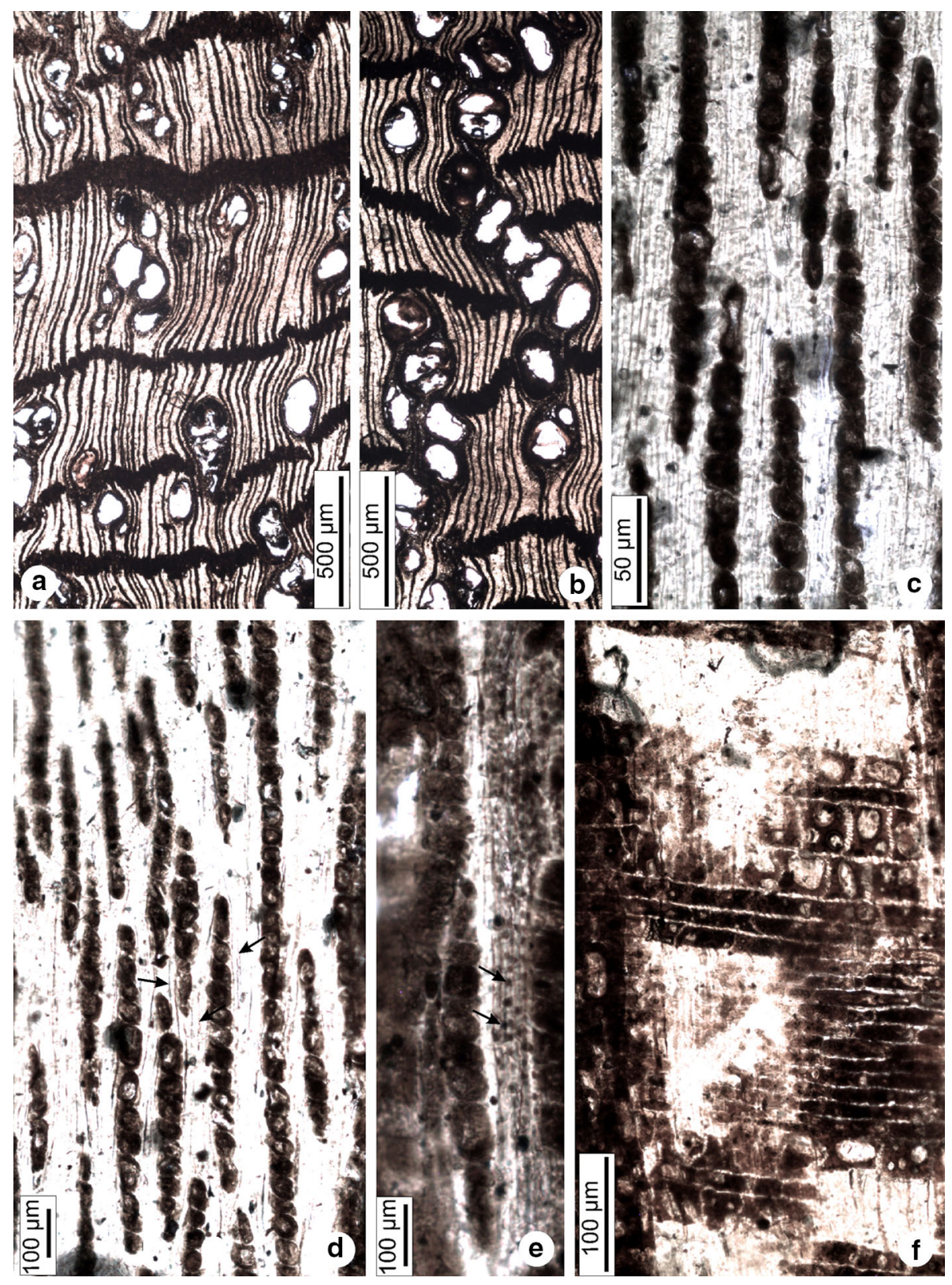

Figure 5. Calophylloxylon cuddalorense Lakhanpal and Awasthi showing (a) distribution of vessels and apotracheal bands of axial parenchyma, (b) vessels arranged in an oblique pattern, (c) uniseriate rays, (d) distribution of rays and non-septate fibres, (e) vasicentric tracheids, and (f) weakly heterogeneous ray tissue.

Ilic 1991). However, Parinari can be differentiated in having thinner bands of axial parenchyma (Kribs 1959). Tandon and Purkayastha (1958) provided a key to separate various genera of the family Clusiaceae and a perusal of this key indicates that our fossil is very close to Calophyllum L. and Mesua L. Both these genera are now placed in Calophyllaceae. Our fossil can be differentiated from Mesua in having comparatively less thick walled fibres and less closely spaced axial parenchyma bands (Lakhanpal and Awasthi 1965; Prakash 1966a) and hence, can be assigned to Calophyllum. Published descriptions and photographs (Pearson and Brown 1932; Tandon and Purkayastha 1958; Kribs 1959; Miles 1978; Ilic 1991; http://insidewood.lib.ncsu. $\mathrm{edu} /$ ) of its various species were consulted for detailed comparison. In addition, wood slides of several species of Calophyllum, namely $C$. apetalum Willd. syn. C. wightianum Wall. ex Planch. \& Triana, C. blancoi Planch. \& Triana, C. brasiliense Cambess. (syn. C. lucidum Benth.), C. calaba L. (syn. C. retusum Wall. ex Planch. \& Triana), C. Costatum F.M. Bailey, C. ferrugineum Ridl., C. inophyllum L., C. obliquinervium Merr., 
C. papuanum Lauterb., C. polyanthum Wall. ex Planch. \& Triana, C. tacamahaca Willd. (syn. C. spectabile Willd.), C. tetrapterum Miq. (syn. C. floribundum Hook. f. and C. venustum King) and $C$. tomentosum Wight were also available for comparison at the Birbal Sahni Institute of Palaeosciences, Lucknow. The present fossil wood is identical to $C$. tomentosum Wight (slide no. BSIP232).

Lakhanpal and Awasthi (1965) instituted the genus Calophylloxylon to include the fossil woods showing resemblance with Calophyllum. So far, the following four species of the fossil genus were described from the Neogene of India: Calophylloxylon indicum Lakhanpal and Awasthi (1965) and $C$. cuddalorense Lakhanpal and Awasthi (1965) from the Cuddalore Sandstone of South Arcot District, Tamil Nadu, C. eoinophyllum Prakash (1966a) from the Tipam Group of Deomali, Arunachal Pradesh (Khan et al. 2017) and Calophylloxylon sp. from the Warkalli beds of south India (Awasthi and Anhuja 1982). In addition, two more species, namely C. intermedium Müller-Stoll and Mädel-Angeliewa (1986) from the Tertiary of West Java and C. tiebaghiense Salard-Cheboldaeff et al. (2012) from the Cenozoic of New Caledonia are also known. Our fossil wood is identical to C. cuddalorense, while other species can be differentiated in having thicker rays, thinner axial parenchyma bands or lesser vessel frequency. Hence, the present fossil has been kept under Calophylloxylon cuddalorense.

Calophyllum is a genus of about 80 species of trees distributed in tropics of both the hemispheres, but majority is found in the Indian subcontinent and southeast Asia. C. tomentosum, the modern comparable species of the fossil, occurs in the evergreen forests of Western Ghats, ascending up to $1500 \mathrm{~m}$ elevation (Tandon and Purkayastha 1958).

Genus: Kayeoxylon Chowdhury and Tandan (1949)

Kayeoxylon assamicum Chowdhury and Tandan (1949)

(figure 6a-f)

Description: Wood diffuse porous (figure 6a). Growth rings absent. Vessels circular to oval, tangential diameter range $38-104 \mu \mathrm{m}$ and average $61 \mu \mathrm{m}$, almost solitary, tylosed, rarely forming oblique arrangement, $13-28$ vessels per $\mathrm{mm}^{2}$ (figure $6 \mathrm{a}, \mathrm{b})$; vessel elements $27-111 \mu \mathrm{m}$ in length with horizontal to oblique ends; perforations simple. Vasicentric tracheids rarely present. Axial parenchyma apotracheal banded, bands mostly continuous, sometimes broken, 3-13 cells wide, bandwidth $95-160 \mu \mathrm{m}$, regularly spaced. Rays 22-24 per $\mathrm{mm}, 1-2$, rarely 3 seriate; uniseriates $2-4$ cells or $62-121 \mu \mathrm{m}$ high, $9-12 \mu \mathrm{m}$ in width, multiseriates $16-23$ cells or $144-515 \mu \mathrm{m}$ in height, $19-23 \mu \mathrm{m}$ in width (figure 6c, d); ray tissue heterogenous; rays mostly made up of procumbent cells with extensions of $1-5$ rows of upright cells, uniseriate rays made of upright cells; procumbent cells $10-15 \mu \mathrm{m}$ in tangential height and $21-51 \mu \mathrm{m}$ in radial length; square cells $25-40 \mu \mathrm{m}$ in tangential height, $28-41 \mu \mathrm{m}$ in radial length (figure 6f). Fibres libriform, polygonal in section, non-septate, $36-58 \mu \mathrm{m}$ in width; occasionally with bordered pits (figure 6e).

Figured specimen: Specimen no. BSIP41161.

Horizon: Upper Siwalik (= Kimin Formation).

Locality: $1 \mathrm{~km}$ before Nirjuli on the NirjuliBanderdeva road.

Age: Late Pliocene-Early Pleistocene.

Affinities: The characteristic features of the fossil wood are: diffuse porous wood, thick apotracheal banded axial parenchyma, solitary and tylosed vessels, simple perforation plates, vasicentric tracheids, 1-3 seriate rays and non-septate libriform fibres with bordered pits. They indicate its affinities with the family Clusiaceae (Pearson and Brown 1932; Kribs 1959; Miles 1978; Ilic 1991). Chowdhury and Tandan (1949) prepared a list of taxa having diffuse porous woods with alternate bands of parenchyma and fibres and concluded that only Kayea Wall. of the Clusiaceae (now placed under Calophyllaceae) has the tendency to form oblique radial pattern. The other closely allied genera of the family are Calophyllum L. and Mesua L. which have larger but fewer vessels with more pronounced oblique pattern (Tandon and Purkayastha 1958). In view of the above-mentioned facts, the present fossil shows maximum similarities with Kayea. Tandon and Purkayastha (1958) studied woods of two species of Kayea, namely K. kunsteleri King and $K$. nervosa T. And. and found both of them anatomically indistinguishable.

Chowdhury and Tandan (1949) established the genus Kayeoxylon to include fossil woods showing affinities with Kayea. The only species of the fossil genus known so far is K. assamicum Chowdhury and Tandan described from the Tipam Group (late Miocene) of Assam. Later on, Prakash and Tripathi (1975) and Bande and Srivastava (1988) also recorded it from the Neogene of Assam and 


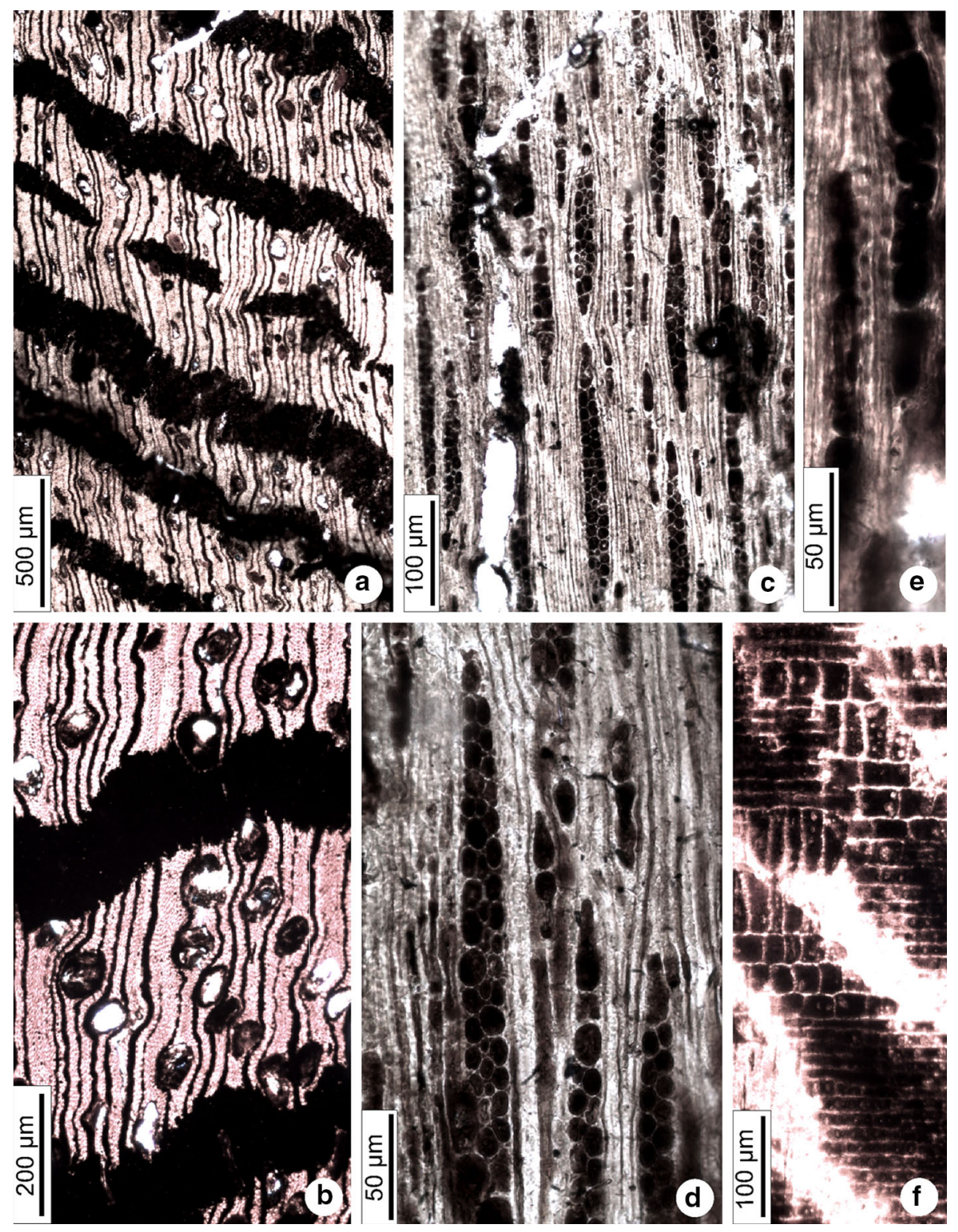

Figure 6. Kayeoxylon assamicum Chowdhury and Tandan showing (a) distribution of vessels and thick apotracheal bands of axial parenchyma, (b) shape, size and distribution of vessels, (c) structure of rays, (d) mostly 1-2 seriate rays and non-septate fibres, (e) pits in fibres, and (f) heterogenous ray tissue.

West Bengal, respectively. As our fossil is also very similar to Kayeoxylon assamicum, it has been assigned to it.

Kayea is a tropical genus of small to medium trees and occurs in south and southeast Asia. Five species of it are found in India and Myanmar. In India, they are found in Assam, Sikkim and Andamans, especially in sub-montane forests (Tandon and Purkayastha 1958).

Family: Celastraceae

Genus: Lophopetalumoxylon Mehrotra et al. (1984)
Lophopetalumoxylon indicumMehrotra et al. (1984) (figure $7 \mathrm{a}-\mathrm{e}$ )

Description: Wood diffuse porous (figure 7a). Growth rings distinct, delimited by fibrous tissue. Vessels deformed due to compression, mostly small, tangential diameter range $72-97 \mu \mathrm{m}$ and average $74 \mu \mathrm{m}$, solitary and in radial pairs, about 24 per $\mathrm{mm}^{2}$, without tyloses and evenly distributed; vessel elements $42-141 \mu \mathrm{m}$ in length with horizontal to oblique ends; perforations simple (figure 7a, b); intervessel pits bordered, alternate, 5-7 $\mu \mathrm{m}$ in diameter (figure $7 \mathrm{~d}$ ). Axial parenchyma 

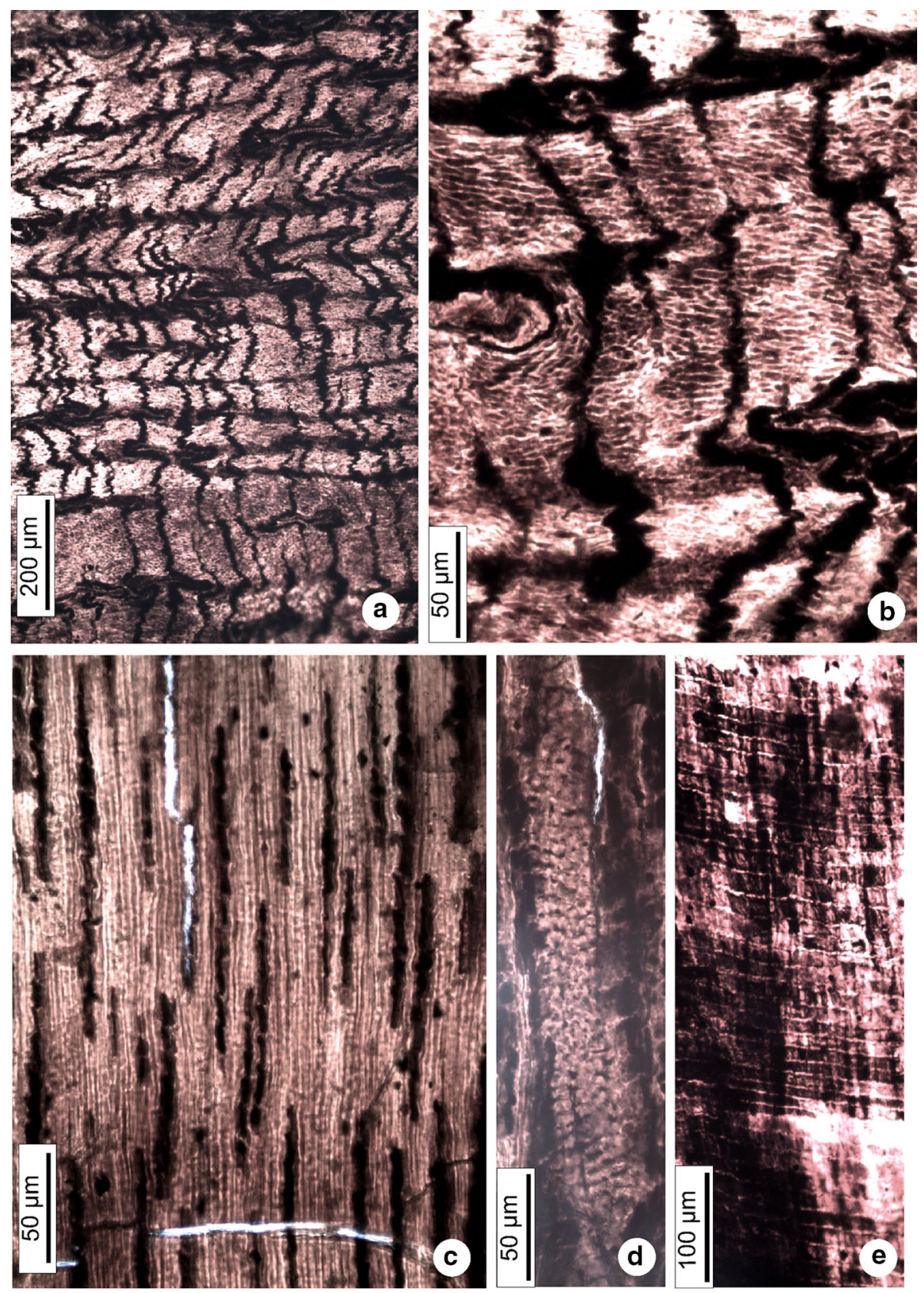

Figure 7. Lophopetalumoxylon indicum Mehrotra et al. showing (a) thin apotracheal bands of axial parenchyma, (b) thick walled fibres and structure of vessels, (c) uniseriate rays, (d) intervessel pits, and (e) homogeneous ray tissue.

apotracheal in the form of thin $(2-4$ celled), wavy bands (figure $7 \mathrm{a}, \mathrm{b}$ ); cells $6.5-8.5 \mu \mathrm{m}$ in length and $5-6 \mu \mathrm{m}$ in width. Rays uniseriate, 20-21 per $\mathrm{mm}, 2-8$ cells or $28-154 \mu \mathrm{m}$ high, $4-6 \mu \mathrm{m}$ in width, made up of procumbent cells (figure $7 \mathrm{c}$ ); ray tissue homogeneous, ray cells $17-43 \mu \mathrm{m}$ in radial length and $11-21 \mu \mathrm{m}$ in tangential height (figure $7 \mathrm{e}$ ). Fibres angular in cross section, thick walled, nonseptate, $3-4 \mu \mathrm{m}$ in diameter. Intercellular canals absent.

Figured specimen: Specimen no. BSIP41162.

Horizon: Middle Siwalik (= Subansiri Formation).
Locality: Along Pappu Nala near the NaharlagunBanderdeva road.

Age: Early Pliocene.

Affinities: The characteristic features of the fossil wood are: diffuse porous wood, vessels small solitary and in radial pairs, simple perforations, bordered alternate intervessel pits, thin apotracheal bands of axial parenchyma, uniseriate, homocellular rays, non-septate thick walled fibres and absence of intercellular canals. These characters cumulatively indicate their resemblance with 
Celastraceae (Pearson and Brown 1932; Metcalfe and Chalk 1950; Kribs 1959; Miles 1978; Ilic 1991). The fossil also shows some resemblance with $\mathrm{Bau}$ hinia L. of the Fabaceae and Terminalia L. of the Combretaceae. The former can be differentiated from the present fossil in having either storied rays or heterogeneous ray tissue, while the latter is distinct in possessing generally paratracheal parenchyma and septate fibres. Nigam (1963) proposed a key to differentiate various Indian genera of the Celastraceae and a perusal of this key indicates that our fossil is close to Lophopetalum Wight and Kokoona littoralis Lawson (syn. Lophopetalum littorale Ridl.), especially with the latter (slide no. BSIP3419).

Mehrotra et al. (1984) instituted the genus Lophopetalumoxylon for the fossil woods resembling Lophopetalum, including $L$. littorale. Its only species, Lophopetalumoxylon indicum was described from the Deccan Intertrappean beds of Dindori District, Madhya Pradesh (Mehrotra et al. 1984). The present fossil is identical to it and therefore, is kept under the same species.

Lophopetalum littorale, the modern comparable form of the fossil, is a large tree growing in Myanmar on low lands inundated during the rains (Nigam 1963).

Family: Ebenaceae

Genus: Ebenoxylon Felix (1882)

Ebenoxylon siwalicus Prakash (1981)

(figure 8a-d)

Description: Wood diffuse porous (figure 8a). Growth rings present marked by denser fibres (figure 8a). Vessels mostly small to medium, crushed due to compression, tangential diameter range 28-77 $\mu \mathrm{m}$ and average $66 \mu \mathrm{m}$, radial diameter $43-$ $210 \mu \mathrm{m}$, solitary and in radial multiples of $2-6$, 16-21 per $\mathrm{mm}^{2}$, evenly distributed, tylosed (figure 8a); vessel elements 180-206 $\mu \mathrm{m}$ in length with horizontal to oblique ends; perforations simple; intervessel pits alternate, round, about $6-7 \mu \mathrm{m}$ in diameter. Axial parenchyma paratracheal scanty and apotracheal thin (mostly one celled thick) reticulate (figure 8a). Rays 1-3 (mostly 1-2) seriate, 25-30 per mm; uniseriates made up of upright cells, 3-23 cells or $76-861 \mu \mathrm{m}$ high, $6-16 \mu \mathrm{m}$ in width; multiseriates made up of procumbent cells with $1-4$ rows of upright cells, $18-60 \mu \mathrm{m}$ in width and 18-40 cells or $288-931 \mu \mathrm{m}$ high (figure 8b, c); ray-to-ray fusion observed; ray cells mostly filled with dark contents; ray tissue heterogeneous, procumbent cells $43-55 \mu \mathrm{m}$ in radial length and $17-$ $27 \mu \mathrm{m}$ in tangential height, upright cells $32-46 \mu \mathrm{m}$ in radial length and $54-60 \mu \mathrm{m}$ in tangential height (figure 8d). Fibres angular in cross section, thick walled and non-septate.

Figured specimen: Specimen no. BSIP41163.

Horizon: Upper Siwalik (= Kimin Formation).

Locality: Near $7 \mathrm{~km}$ post on the ItanagarBanderdeva road.

Age: Late Pliocene-Early Pleistocene.

Affinities: The characteristic features of the fossil wood such as diffuse porous wood, small to medium vessels arranged in radial multiples of $2-$ 6 , simple perforations, mostly thin reticulate axial parenchyma, predominantly 1-2 seriate rays, heterogeneous ray tissue and non-septate fibres indicate its affinity with modern woods of the families Apocynaceae, Ebenaceae, Myrtaceae, Rubiaceae and Sapotaceae (Pearson and Brown 1932; Metcalfe and Chalk 1950). However, the occurrence of vasicentric tracheids in woods of Apocynaceae, Myrtaceae, Rubiaceae and Sapotaceae differentiates them from the present fossil. Moreover, some genera of Myrtaceae have exclusively solitary vessels. Among various genera of the Ebenaceae, woods of Diospyros Linn. show near resemblance with the present fossil (Pearson and Brown 1932; Kribs 1959; Miles 1978; Kazmi 1982; Ilic 1991; http://insidewood.lib.ncsu.edu/). Besides published description and photographs, wood slides of the following species of Diospyros, namely D. evena Bakh., D. guianensis (Aubl.) Gürke, D. kurzii Hiern, D. macrophylla Bl., D. malabarica (Desr.) Kostel., D. melanoxylon Roxb., D. pentamera (F. Muell.) Woods and F. Muell., D. pyrrhocarpa Miq. and $D$. virginiana $\mathrm{L}$. were consulted. The present fossil shows maximum resemblance with $D$. melanoxylon.

Felix (1882) established the genus Ebenoxylon for the fossil woods of Diospyros. Total 15 species of the genus are known from various parts of the world and are mentioned below: Ebenoxylon aegypticum Kräusel (1939) and E. ebenoides Kräusel (1939) from the Tertiary of Libya, E. indicum Ghosh and Kazmi (1958) from the late Miocene-Pliocene of Arunachal Pradesh, E. arcotense Awasthi (1970, 1984) from the late Miocene-Pliocene of Pondicherry, E. kartikcherraense Prakash and Tripathi (1970) from the Tipam Sandstone (late Miocene) of Assam, E. mohgaoense Chitaley and Patil (1972) and E. deccanensis Trivedi and Srivastava (1982) from the Deccan Intertrappean beds of central 

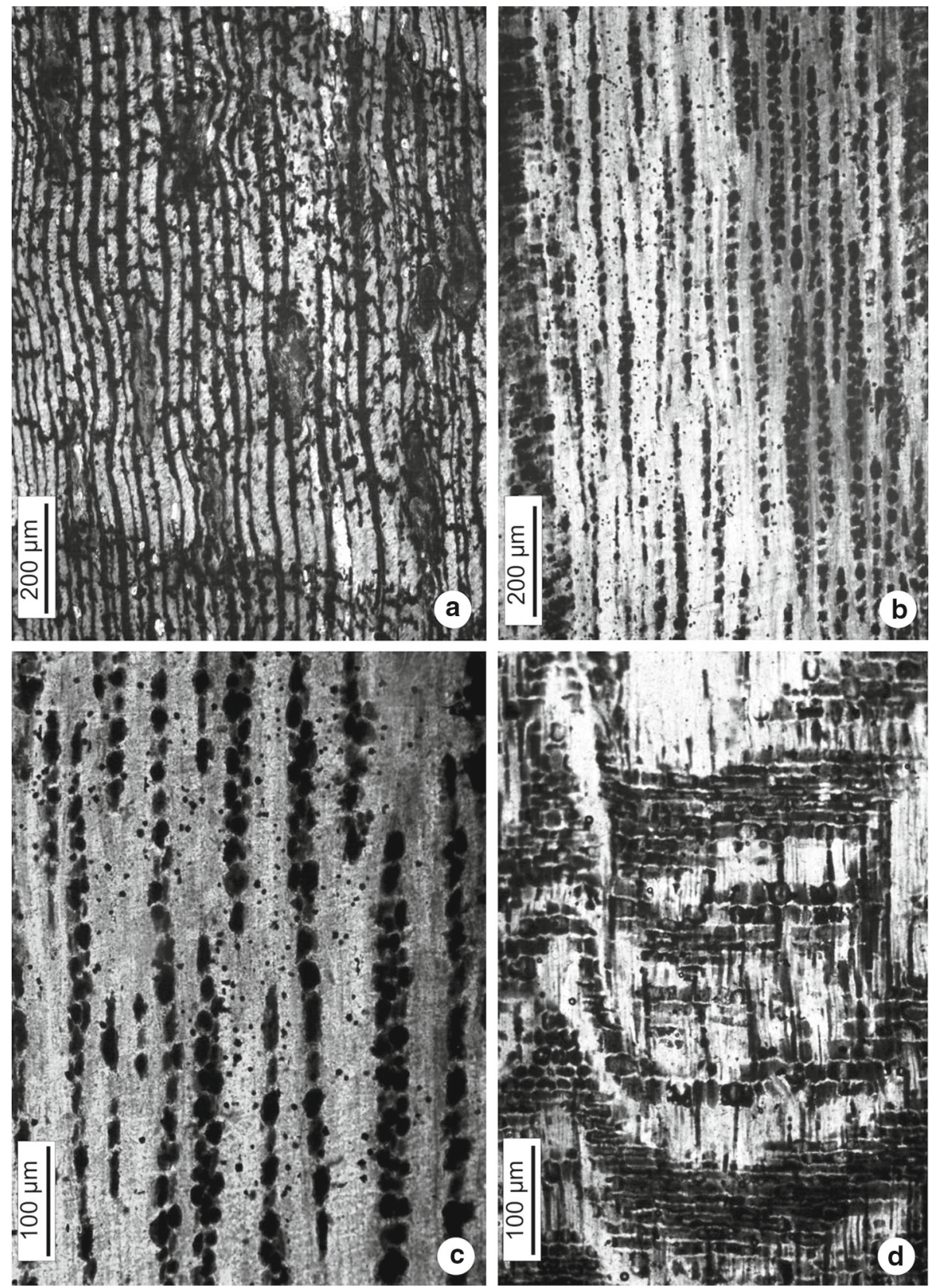

Figure 8. Ebenoxylon siwalicus Prakash showing (a) thin reticulate lines of axial parenchyma, (b) distribution of rays, (c) structure of 1-2 seriate rays and non-septate fibres, and (d) heterogeneous ray tissue.

India, E. bavaricum Selmeier (1976) from the Miocene of Bavaria, E. miocenicum Prakash (1978), E. siwalicus Prakash (1981), E. kalagarhensis Prasad (1989) and E. palaeocalendula Prasad (1993) from the Siwalik sediments of Uttarakhand, $E$. obliquiporosum Awasthi and Anhuja (1982) from the late Miocene-Pliocene of Kerala, E. burmense $\mathrm{Du}$ (1988) from the Pliocene of Myanmar and E. neyveliensis Mukherjee and Prasad (2013) from the late Miocene-Pliocene Neyveli lignite deposits of Tamil Nadu. Many of them are based on minor characters, possibly due to intraspecific variations and, therefore, are difficult to be distinguished. The present fossil was compared with all of them and found close to Ebenoxylon siwalicus Prakash. The other species have either thinner rays or more paratracheal parenchyma.

Diospyros is a genus of about $450-500$ species widely distributed in tropical and mild temperate regions of the world. D. melanoxylon, the modern counterpart of the fossil, is a common tree of mixed deciduous forests of peninsular India (Kazmi 1982). 


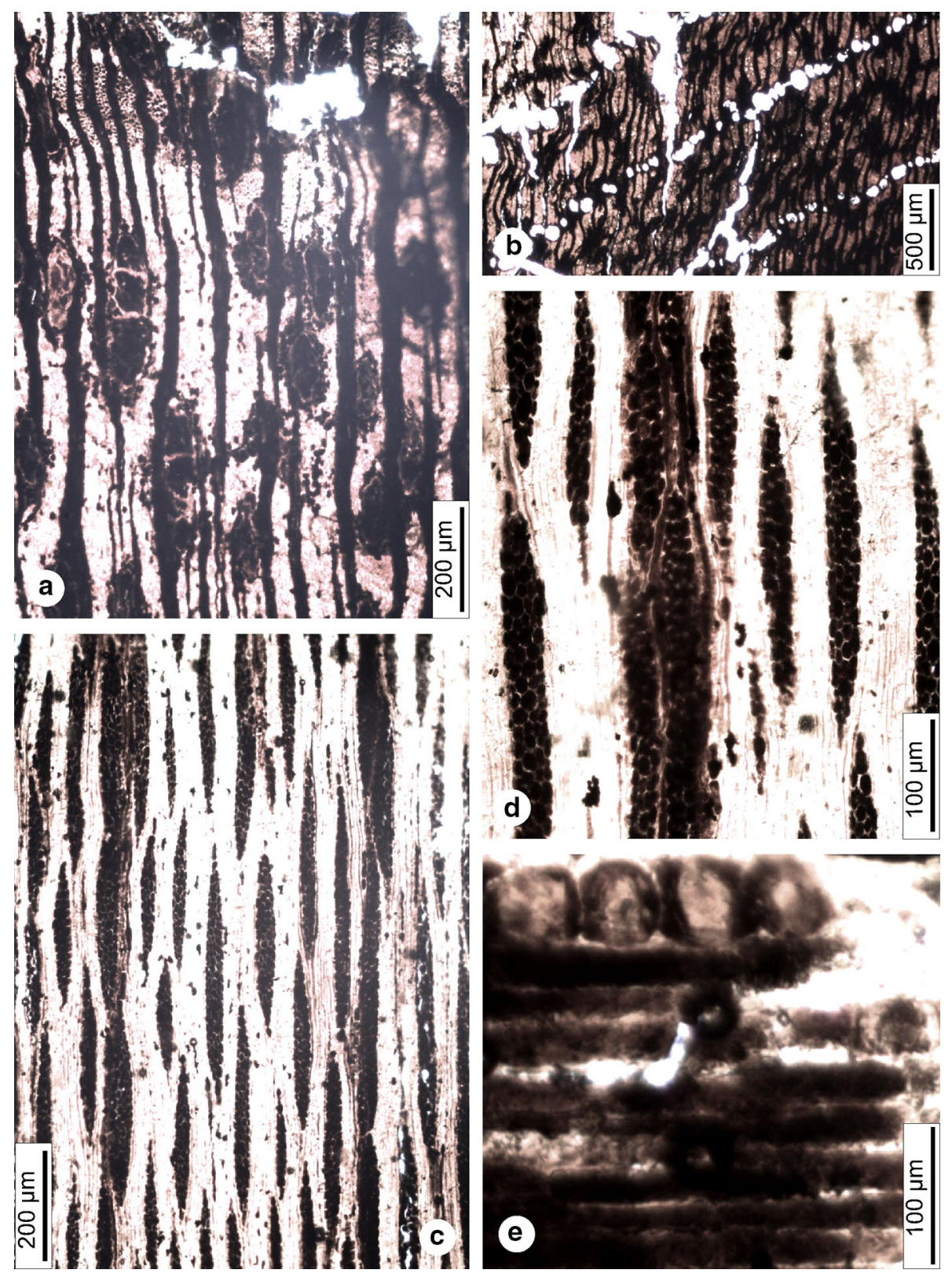

Figure 9. Hopeoxylon eosiamensis Prakash showing (a) distribution of small to medium vessels, (b) concentric rows of vertical canals enclosed in axial parenchyma bands, (c) structure of rays, (d) 1-4 seriate rays and non-septate fibres, and (e) heterogenous ray tissue.

\section{Family: Fabaceae}

Genus: Hopeoxylon (Navale) Awasthi (1977) Hopeoxylon eosiamensis Prakash (1981)

(figure 9a-e)

Description: Wood diffuse porous (figure 9a). Growth rings delimited by thin bands of terminal parenchyma enclosing gum canals, bands 340-760 $\mu \mathrm{m}$ apart (figure 9a, b). Vessels round to oval, mostly small to medium sized, tangential diameter range $42-78 \mu \mathrm{m}$ and average $63 \mu \mathrm{m}$, radial diameter $44-138 \mu \mathrm{m}$, solitary and in radial multiples of 2 to $3,22-30$ per $\mathrm{mm}^{2}$, evenly distributed, dark brown gummy deposits present inside the vessels (figure 9a); vessel elements $147-180 \mu \mathrm{m}$ in length with horizontal to oblique ends; perforations simple. Axial parenchyma paratracheal and apotracheal; paratracheal vasicentric forming 1-3 celled sheath around the vessels to aliform to confluent; apotracheal terminal enclosing the gum canals and thin short broken bands also observed (figure 9a, b). Rays 1-4 (mostly 2-3) seriate, 18-22 per mm; uniseriates rare, 6-9 cells or 150-160 $\mu \mathrm{m}$ high, 11$27 \mu \mathrm{m}$ in width; multiseriates $2-5$ seriate, mostly 
made up of procumbent cells with 1 or 2 rows of upright or square cells, $18-46 \mu \mathrm{m}$ in width and $12-$ 27 cells or $155-588 \mu \mathrm{m}$ in height (figure $9 \mathrm{c}, \mathrm{d}$ ); ray tissue heterogeneous, procumbent cells $36-56 \mu \mathrm{m}$ in radial length and $11-14 \mu \mathrm{m}$ in tangential height; upright or square cells $19-36 \mu \mathrm{m}$ in tangential height and $24-38 \mu \mathrm{m}$ in radial length (figure 9e). Fibres polygonal in cross section, thick walled, non-septate, $5-7 \mu \mathrm{m}$ in diameter. Gum canals normal, vertical in concentric rings and embedded in parenchyma bands, $80-150 \mu \mathrm{m}$ in diameter (figure 9b).

Figured specimen: Specimen no. BSIP41164.

Horizon: Middle Siwalik (=Subansiri Formation). Locality: Along Pappu Nala near the NaharlagunBanderdeva road.

Age: Early Pliocene.

Affinities: The characteristic features of the fossil wood, viz., concentric rings of gum canals embedded in terminal parenchyma bands, vasicentric to aliform-confluent axial parenchyma, simple perforations, 1-4 seriate rays with heterogeneous ray tissue and non-septate fibres indicate its affinity with the xylotomically similar taxa Copaifera Linnaeus, Detarium Jussieu and Sindora Miquel of the Fabaceae (Metcalfe and Chalk 1950; Normand 1950; Kribs 1959; Ilic 1991). The fossil does show superficial resemblance with Daniella Benn. and Sindoropsis J. Léonard of the Fabaceae and Shorea Roxb. ex C.F. Gaertn. of the Dipterocaropaceae. However, Daniellia is distinct in having storied elements; Sindoropsis has slightly narrower rays and intercellular canals in short tangential rows, while Shorea can be differentiated in having vasicentric tracheids (http://insidewood.lib.ncsu. $\mathrm{edu} /$ ). Besides published literature, wood slides of two species of Detarium, namely D. macrocarpum Harms and D. senegalense J.F. Gmel. and seven species of Sindora, viz., S. beccariana de Wit, S. echinocalyx Prain, S. irpicina de Wit, S. siamensis Miq. (syn. S. cochinchinensis Baill.), S. supa Merr., S. tonkinensis A. Chev. and $S$. velutina Baker were available for study. Of them, our fossil shows maximum resemblance with S. siamensis Miq. The genus Copaifera occurs in tropical America and Africa, while Detarium is confined to tropical Africa only. Sindora is usually found in southeast Asia, Hainan, western Malaysia, Celebes and Molucca (Ridley 1967; Willis 1973).

Fossil woods resembling Sindora and allied forms, such as Copaifera and Detarium were described under the fossil genus Hopeoxylon (Navale) Awasthi (1977). So far nine species of the genus, namely $H$. aethiopicum (Lemoigne et al.) Lalitha and Prakash (1980) from the Miocene of Ethiopia, H. arcotense Awasthi (1977) from the Neogene of south India, H. assamicum Lalitha and Prakash (1980) from the Miocene of Assam and West Bengal (Bera et al. 2001), H. eosiamensis Prakash (1981) from the Lower Siwalik sediments of Uttarakhand, $H$. indicum (Navale) Awasthi (1977) from the Neogene of south India and Oligo-Miocene of Saudi Arabia (Prive-Gill et al. 1999), H. libycum (Boureau and Louvet) Lalitha and Prakash (1980) from the Palaeogene of Libya, Algeria and Tunisia, H. migiurtinum (Chiarugi) Lalitha and Prakash (1980) from the Miocene of Somalia, H. sindoroides (Kramer) Lalitha and Prakash (1980) from the Tertiary of West Kalimantan and S. speciosum (Navale) Awasthi (1977) from the Neogene of south, north (Prakash et al. 1988) and northeast India (Mehrotra et al. 2005) are known (Prakash et al. 1988, Prive-Gill et al. 1999). Of them, $H$. arcotense was considered by Prakash et al. (1988) as synonym to $H$. speciosum. The present fossil shows maximum resemblance with $H$. eosiamensis and hence has been assigned to it. The other species can be distinguished from our fossil in width, height and homogeneity of the rays.

Sindora siamensis, the modern comparable species of the fossil, is a large evergreen tree found in open semi-deciduous forests of Kampuchea, Laos, Malaysia, Thailand and Vietnam.

Genus: Pahudioxylon Chowdhury et al. (1960) Pahudioxylon indicum Prakash (1979) (figure 10a-f)

Description: Wood diffuse porous (figure 10a, b). Growth rings marked by terminal parenchyma (figure 10a). Vessels round to oval, mostly medium to large, tangential diameter range $76-199 \mu \mathrm{m}$ and average $119 \mu \mathrm{m}$, mostly solitary, occasionally in radial pairs, $10-16$ per $\mathrm{mm}^{2}$, evenly distributed, filled with black gummy deposits (figure 10a, b); vessel elements $59-173 \mu \mathrm{m}$ in length with horizontal to oblique ends; perforations simple; intervessel pits alternate, vestured, $5-7 \mu \mathrm{m}$ in size (figure 10e). Axial parenchyma both apotracheal and paratracheal; apotracheal terminal in the form of onecelled thick band, bands about $850 \mu \mathrm{m}$ apart, paratracheal vasicentric to aliform to confluent (figure 10a, b). Rays 1-3 (mostly bi) seriate, 8-14 


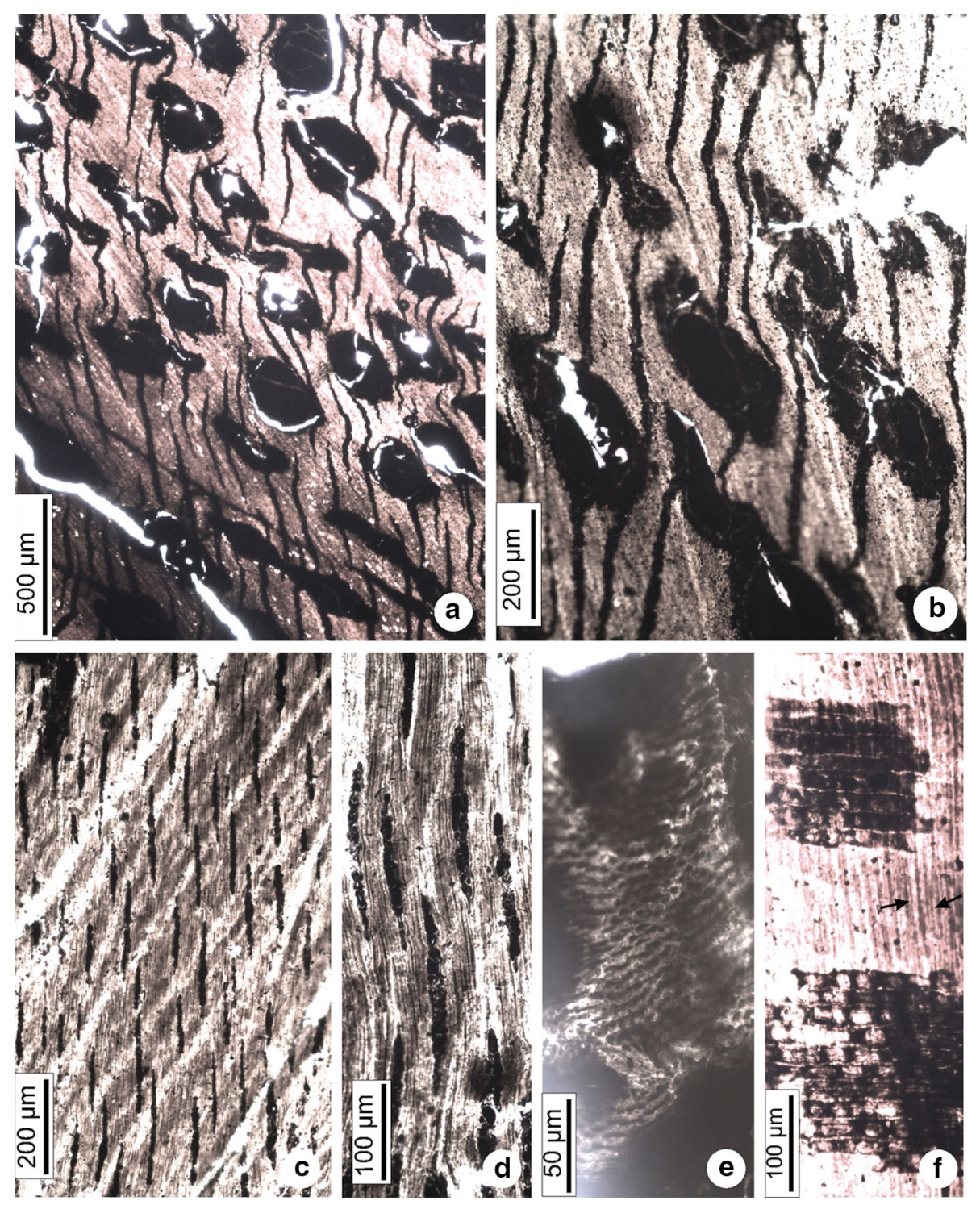

Figure 10. Pahudioxylon indicum Prakash showing (a) medium to large vessels and terminal parenchyma, (b) vasicentric to aliform axial parenchyma, (c) structure of rays, (d) 1-3 seriate rays and non-septate fibres, (e) vestured intervessel pits, and (f) homogeneous ray tissue.

per mm, irregularly storied, made up of procumbent cells, $11-21 \mu \mathrm{m}$ in width and $3-22$ cells or 60-286 $\mu \mathrm{m}$ in height (figure 10c, d); ray tissue homogeneous; ray cells filled with dark contents, 27-46 $\mu \mathrm{m}$ in radial length and $17-26 \mu \mathrm{m}$ in tangential height (figure 10f). Fibres polygonal in cross section, thick walled, non-septate, $3.5-4.5 \mu \mathrm{m}$ in diameter.

Figured specimen: Specimen no. BSIP41165.

Horizon: Middle Siwalik (= Subansiri Formation). Locality: Along Pappu Nala near the NaharlagunBanderdeva road.

Age: Early Pliocene.

Affinities: The important features of the fossil wood, viz., diffuse porous wood, growth rings marked by terminal parenchyma, mostly solitary vessels filled with black gummy deposits, simple perforations, vestured intervessel pits, mostly aliform-confluent axial parenchyma, 1-3 seriate, homocellular, irregularly storied rays and nonseptate fibres indicate its affinities with anatomically inseparable genera Afzelia Sm.-Intsia Thouars of the Fabaceae (Pearson and Brown 1932; Metcalfe and Chalk 1950; Kribs 1959; Ramesh et al. 1972; Ilic 1991). However, our fossil resembles the best with I. bijuga (Colebr.) Kuntze (slide no. BSIP810). There are some more genera of the Fabaceae, namely Aphanocalyx Oliv., Baikiaea Bentham \& Hooker f., Brachystegia Benth., Caesalpinia L. and Cassia L. showing some resemblance with the fossil. Aphanocalyx in having 
mostly exclusively uniseriate rays can be differentiated from our fossil, whereas Baikiaea possesses banded parenchyma also and is therefore, distinct from our fossil. In Brachystegia rays, vessel elements and fibres, etc., are all typically storied; Caesalpinia has all rays storied and often lack marginal parenchyma, whereas rays are generally non-storied in Cassia.

Chowdhury et al. (1960) instituted the genus Pahudioxylon for the fossil woods showing similarities with those of Pahudia Miq. As Pahudia was already merged with Afzelia, Prakash (1966b) redefined the genus Pahudioxylon to include fossil woods of Afzelia and Intsia also. So far, 18 species of it are known from various Cenozoic exposures of the world: P. bankurensis Chowdhury et al. (1960), P. bengalensis Ghosh and Roy (1982) and P. garbetaense Bera and Banerjee (2001) from West Bengal, P. sahnii Ghosh and Kazmi (1961) from Tripura, P. arcotense Navale (1963) from Pondicherry, P. deomaliense Prakash (1966b) from Arunachal Pradesh, P. assamicum Prakash and Tripathi (1975) from Assam, P. indicum Prakash (1979) from Himachal Pradesh (all from India), P. afzelioides (Boureau) Prakash et al. and P. kiliani (Louvet) Prakash et al. from IndoChina and Algeria, respectively (Prakash et al. 1967), P. menchikoffi (Boureau) Müller-Stoll and Mädel-Angeliewa (1967) from Algeria, P. irregulare (Felix) Müller-Stoll and Mädel-Angeliewa and P. pannonicum (Felix) from Antigua and Hungary respectively (Müller-Stoll and Mädel-Angeliewa 1967), P. welkitii Lemoigne and Beauchamp (1973) from Ethiopia, P. gehannemense Louvet (1975) from Libya, P. paracochinchinense VozeninSerra (1981) from South Vietnam and P. furoni (Koeniguer) Guleria (1984) and P. aethiopcum (Lemoigne et al.) Guleria (1984) from the Republic of Chad and Ethiopia, respectively (http:// insidewood.lib.ncsu.edu/). Most of these species were established on the basis of minor variations and there is a possibility that some of them could be merged into one another. We have compared our fossil in detail, especially with the Indian species and found that our fossil shows maximum similarities with $P$. indicum Prakash (1979) known from the Siwalik of Himachal Pradesh. The only difference was in the frequency of vessels which is more in number in the present fossil. The other species are distinct in having either broader rays or thicker terminal bands of parenchyma. In order to avoid creation of a new species, we have kept our fossil under Pahudioxylon indicum.
Afzelia is a genus of 12 species distributed in tropical Africa and Asia (Willis 1973; Mabberley 1997), whereas Intsia consists of nine species found in offshore islands of tropical east Africa, Madagascar and tropical Asia. Intsia bijuga, the nearest comparable species of the fossil, occurs in tidal forests of Sunderbans, Andaman Islands and Myanmar.

\section{Discussion}

On land, the distribution of biota is mainly governed by its corresponding climatic conditions (Jansson 2003; Woodward et al. 2004) and this can be viewed even in the fossil records (Jansson 2003; Srivastava and Mehrotra 2013; Srivastava et al. 2015). So the fossil records are important to reconstruct the ancient climate and distribution of the organisms.

The Nearest Living Relative (NLR) approach is used for the reconstruction of palaeoecology and palaeoclimatology. This method considers that the climatic requirements of a fossil taxon are similar to the ones of its NLR and is confidently used by the palaeobotanists in the palaeoclimate reconstruction (Bande and Chandra 1990; Prakash et al. 1994; Estrada-Ruiz et al. 2007; Jeong et al. 2009; Srivastava et al. 2009; Feng et al. 2010; Bamford 2011; Mehrotra et al. 2011, 2013, 2016; Tiwari et al. 2012; Licht et al. 2014, 2015). The modern analogues of the fossil assemblage are: Miliusa velutina (Annonaceae), Calophyllum tomentosum and Kayea (Calophyllaceae), Lophopetalum littorale (Celastraceae), Diospyros melanoxylon (Ebenaceae), Intia bijuga and Sindora siamensis (Fabaceae). It is interesting to note that Calophyllum tomentosum is restricted to wet evergreen forests of Western Ghats and Sri Lanka, while Kayea is found in wet evergreen forests of south and southeast Asia. Sindora siamensis is deciduous to semi-evergreen tree now growing in southeast Asia. The modern analogues of the fossil assemblages are mainly growing in the tropical wet evergreen to moist deciduous forests indicating high rainfall; moreover, the presence of legumes and Diospyros melanoxylon indicates seasonality in the rainfall. The presence of Lophopetalum littorale and Intsia bijuga again supports the presence of high rainfall.

Plants have limited options to escape from adverse environmental conditions. Under such circumstances, they modify their external as well as 
internal architectural features for adaption. The modification in architectural structures, regardless of their taxonomic affinities, can be viewed either externally (Bailey and Sinnott 1915, 1916; Wolfe and Upchurch 1987; Spicer et al. 2011) or internally (Carlquist 1975, 1977, 1988; Baas 1976, 1986). These modified architectural features are often used in the reconstruction of palaeoclimate (Bailey and Sinnott 1915, 1916; Wolfe 1979; Wheeler and Baas 1991, 1993; Wiemann et al. 1998; Poole 2000; Mehrotra et al. 2011; Spicer et al. 2011; Srivastava et al. 2012; Tiwari et al. 2012). In case of woods, several anatomical features have been identified which directly or indirectly represent their corresponding climatic conditions such as density and diameter of vessels, presence or absence of growth rings, diffuse porosity, vessel grouping, structure of perforation plate, intervessel pitting, extent of parenchyma and nature of ray (Wolfe and Upchurch 1987; Wheeler and Baas 1993; Woodcock and Ignas 1994). The characters such as diffuse porosity and indistinct growth rings in woods, large diameter of vessels with low density conjointly infer tropical climate with low seasonality (little variation) in temperature (Wheeler and Baas 1993; Woodcock and Ignas 1994). The dominance of diffuse porosity in woods of Lower and Upper Siwalik infers a tropical climate with little seasonality in the warm and cold month temperatures. The high proportion of large vessels and simple perforation plates in the present assemblages suggest high precipitation (Wolfe and Upchurch 1987). The presence of simple perforation plates often represents an adaptation to more efficient water transport (Wheeler and Baas 1993). All the aforesaid-inferences get more support from the previous quantitative palaeoclimate analysis, based on the leaf architecture, done by Khan et al. (2014a).

\section{Acknowledgements}

The authors are thankful to the Director, Birbal Sahni Institute of Palaeosciences, Lucknow for permission to publish the paper. They are grateful to Prof. Anäis Boura of UPMC, Paris and two anonymous reviewers for their fruitful suggestions to improve our manuscript.

\section{References}

Awasthi N 1970 A fossil wood of Ebenaceae from Tertiary of south India; Palaeobotanist 18 192-196.
Awasthi N 1977 Revsion of Hopeoxylon indicum Navale and Shoreoxylon speciosum Navale from the Cuddalore Series near Pondicherry; Palaeobotanist 24 102-107.

Awasthi N 1984 Studies on some carbonized woods from the Neyveli lignite deposits, India; Geophytol. 14 82-95.

Awasthi N and Ahuja M 1982 Investigation of some carbonized woods from the Neogene of Varkala in Kerala coast; Geophytol. 12 245-259.

Bailey I W and Sinnott E W 1915 A botanical index of Cretaceous and Tertiary climates; Science 41 831-834.

Bailey I W and Sinnott E W 1916 The climatic distribution of certain types of angiosperm leaves; Am. J. Bot. 3 2429.

Bamford M K 2011 Late Pliocene woody vegetation of Area 41, Koobi flora, East Turkana Basin, Kenya; Rev. Palaeobot. Palynol. 164 191-210.

Bande M B 1973 A petrified dicotyledonous wood from the Deccan intertrappean beds of Mandla district, Madhya Pradesh; Botanique 4 41-47.

Bande M B and Chandra S 1990 Early Tertiary vegetational reconstruction around Nagpur-Chhindwara and Mandala, central India; Palaeobotanist 38 196-208.

Bande M B and Srivastava G P 1988 Fossil woods of Guttiferae (Kayea) and Lauraceae from the Tertiary of West Bengal; Geophytol. 18 217-218.

Baas P 1976 Some functional and adaptive aspects of vessel member morphology; Leiden Bot. Ser. 3 157-181.

Baas P 1986 Terminology of imperforate tracheary elementsin defence of libriform fibres with minutely bordered pits; IAWA Bull. N. S. 7 82-86.

Bera S and Banerjee M 2001 Petrified wood remains from Neogene sediments of the Bengal basin, India, with remarks on palaeoecology; Palaeontogr. 260B 167-199.

Bera S, Parua D K and Sen Illora 2001 Fossil wood resembling Sindora Miq. from the Neogene of West Bengal, India; Indian J. Earth Sci. 28 26-31.

Bera S, De A and De B 2004 First record of Elaeocarpus Linn. fruits from the upper Siwalik sediments (Kimin Formation) of Arunachal Pradesh, India; J. Geol. Soc. India 64 350-352.

Bera S and Khan M 2009 Record of fruit and leaflet cf. Pongamia pinnata (L.) Pierre from the upper Siwalik sediments (Kimin Formation) of Arunachal Pradesh; In: Advances in Plant Biology - D Bhattacharya Birth Centenary Commemorative Volume (eds) Mondal S and Bhattacharya S (Berlin: Springer-Verlag), pp. 432-441.

Bera S, Gupta S, Khan M A, De A and Mukhopadhyay R 2014 First megafossil evidence of Cyatheaceous tree fern from the Indian Cenozoic; J. Earth Syst. Sci. 123 14331438.

Carlquist S 1975 Ecological Strategies of Xylem Evolution (Berkeley: California University Press).

Carlquist S 1977 Ecological factors in wood evolution: A floristic approach; Am. J. Bot. 64 887-896.

Carlquist S 1988 Comparative Wood Anatomy: Systematic, Ecological, and Evolutionary Aspects of Dicotyledon Wood (Berlin: Springer).

Chirouze F, Dupont-Nivet G, Huyghe P, van der Beek P, Chakraborti T, Bernet M and Erens V 2012 Magnetostratigraphy of the Neogene Siwalik Group in the far eastern Himalaya: Kameng section, Arunachal Pradesh, India; J. Asian Earth Sci. 44 117-135. 
Chitaley S D and Patil G V 1972 An ebenaceous fossil wood infected with deuteromyceteous fungus from the Deccan Intertrappean beds of India; Botanique 3 99-105.

Chowdhury K A and Tandan K N 1958 Family Annonaceae; In: Indian Woods (eds) Chowdhury K A and Ghosh S S (Delhi: The Manager of Publications) 1 16-30.

Chowdhury K A and Tandan K N 1949 Kayeoxylon assamicum, gen. et sp. nov., a fossil dicotyledonous wood from Assam; Proc. Nat. Inst. Sci. India 15 59-65.

Chowdhury K A, Ghosh S S and Kazmi M H 1960 Pahudioxylon bankurensis gen. et sp. nov. - a fossil dicotyledonous wood from the Miocene beds of Bankura District, West Bengal; Proc. Nat. Inst. Sci. India 26 22-28.

Crawley M 2001 Angiosperm woods from British Lower Cretaceous and Paleogene deposits, In: Special Papers in Palaentology (London: The Palaeontological Association) 66 100p.

Du N 1988 Fossil wood from the late Tertiary of Burma; Proc. Koninklijke Nederlandse Akad. van Wetenschappen 91 Ser. B 213-236.

Estrada-Ruiz E, Martinez-Cabrera H I, Cevallos-Ferriz S R S 2007 Fossil woods from the late Campanian-early Maastrichtian Olmos Formation, Coahuila, Mexico; Rev. Palaeobot. Palynol. 145 123-133.

Felix J 1882 Studien über fossile Hölzer (Leipzig: Diss. Von Pöschel and Trepte).

Feng X X, Yi T M and Jin J H 2010 First record of Paraphyllanthoxylon from China; IAWA J. 31 89-94.

Ghosh P K and Roy S K 1982 Fossil wood of Caesalpinioideae from the Miocene of West Bengal, India; Acta Bot. Indica $1050-55$.

Ghosh S S and Kazmi M H 1958 Ebenoxylon indicum sp. nov., a new fossil record from Tirap Frontier Division, NEFA, Assam; Sci. Cult. 24 187-188.

Ghosh S S and Kazmi M H 1961 Pahudioxylon sahnii sp. nov., a new fossil record from the Miocene(?) of Tripura; Sci. Cult. 27 96-98.

Gregory M, Poole I and Wheeler E A 2009 Fossil dicot wood names - an annotated list with full bibliography; IAWA J. Suppl. 6 1-220.

Guleria J S 1984 Leguminous woods from the Tertiary of District Kachchh, Gujarat, western India; Palaeobotanist 31 238-254.

Ilic J 1991 CSIRO atlas of hard woods (Berlin: Springer).

International Association of Wood Anatomists 1989 IAWA list of microscopic features for hardwood identification; IAWA New Ser. 10 219-332.

Jansson R 2003 Global patterns in endemism explained by past climatic change; Proc. Roy. Soc. London B $270583-$ 590.

Jeong E K, Kim K, Suzuki M and Kim J W 2009 Fossil woods from the Lower coal bearing formation of the Janggi Group (Early Miocene) in the Pohang Basin, Korea; Rev. Palaeobot. Palynol. 153 124-138.

Johnson N M, Stix J, Tauxe L, Cerveny P P and Tahirkheli R A K 1985 Palaeomagnetic chronology, fluvial processes and tectonic implications of the Siwalik deposits near Chinji village, Pakistan; J. Geol. 93 27-40.

Joshi A and Chakraborty P P 2001 Systematic geological mapping in parts of east and west Kameng districts, Arunachal Pradesh; Geol. Surv. India Unpubl. Progress Rep. for F.S. 1999-2000.
Joshi A and Mehrotra R C 2003 A thelypteridaceous fern from the Lower Siwalik of the East Kameng district, Arunachal Pradesh, India; J. Geol. Soc. India 61 483486.

Joshi A and Mehrotra R C 2007 Megaremains from the Siwalik sediments of West and East Kameng districts, Arunachal Pradesh;J. Geol. Soc. India 69 1256-1266.

Joshi A, Mehrotra R C and De A 2003a A fossil wood from the Upper Siwalik sediments of West Kameng District, Arunachal Pradesh, India; Proc. Fourth South Asia Geological Congress (GEOSAS - IV) (Kolkata: The Director General Geol. Surv. India), pp. 312-315.

Joshi A, Tewari R, Mehrotra R C, Chakraborty P P and De A 2003b Plant remains from the Upper Siwalik sediments of West Kameng District, Arunachal Pradesh, India; J. Geol. Soc. India 61 319-324.

Karunakaran C 1974 Geology and mineral resources of the states of India. Part IV - Arunachal Pradesh, Assam, Manipur, Meghalaya, Mizoram, Nagaland and Tripura; Geol. Surv. India Misc. Publ. No. 30 1-124.

Karunakaran C and Ranga Rao A 1979 Status of exploration for hydrocarbons in the Himalayan region - contributions to stratigraphy and structure; Geol. Surv. India Misc. Publ. 41 1-66.

Kazmi S M H 1982 Ebenaceae; In: Indian woods (ed.) Purkayastha S K (Delhi: Controller of Publications) 4 $122-131$.

Khan M and Bera S 2007 Dysoxylum miocostulatum sp. nov. - a fossil leaflet of Meliaceae from the Lower Siwalik sediments of West Kameng district, Arunachal Pradesh, eastern India; Indian J. Geol. 79 63-68.

Khan M and Bera S 2010 Record of fossil fruit wing of Shorea Roxb. from the Neogene of Arunachal Pradesh; Curr. Curr Sci. 98 1573-1574.

Khan M and Bera S 2014 New lauraceous species from the Siwalik forest of Arunachal Pradesh, eastern Himalaya, and their palaeoclimatic and palaeogeographic implications; Turk J. Bot. 38 453-464.

Khan M A and Bera S 2016 First fossil evidence of Connaraceae R. Br. from Indian Cenozoic and its phytogeographical significance; J. Earth Syst. Sci. 125 1079-1087.

Khan M A and Bera S 2017 First discovery of fossil winged seeds of Pinus L. (family Pinaceae) from the Indian Cenozoic and its palaeobiogeographic significance; J. Earth Syst. Sci. 126(5) Article ID 63.

Khan M, De B and Bera S 2008 Fossil leaves resembling modern Terminalia chebula Retzius from the Lower Siwalik sediments of Arunachal Pradesh, India; Pleione 2 38-41.

Khan M, De B and Bera S 2009 Leaf-impressions of Calophyllum L. from the Middle Siwalik sediments of Arunachal Sub-Himalaya, India; Pleione 3 101-106.

Khan M, Ghosh R, Bera S, Spicer R A and Spicer T E V 2011 Floral diversity during Plio-Pleistocene Siwalik sedimentation (Kimin Formation) in Arunachal Pradesh, India and its palaeoclimatic significance; Palaeodivers. Palaeoenviron. 91 237-255.

Khan M A, Spicer R A, Bera S, Ghosh R, Yang J, Spicer T E V, Guo S X, Tao S, Frédéric J and Grote $\mathrm{P} J$ 2014a Miocene to Pleistocene floras and climate of the Eastern Himalayan Siwaliks, and new palaeoelevation estimates for the Namling-Oiyug Basin, Tibet; Global Planet. Change 113 1-10. 
Khan M A, Spicer T E V, Spicer R A and Bera S 2014b Occurrence of Gynocardia odorata Robert Brown (Achariaceae, formerly Flacourtiaceae) from the Plio-Pleistocene sediments of Arunachal Pradesh, northeast India and its palaeoclimatic and phytogeographic significance; Rev. Palaeobot. Palynol. 211 1-9.

Khan M A, Bera S, Ghosh R, Spicer Robert A and Spicer T E V 2015 Leaf cuticular morphology of some angiosperm taxa from the Siwalik sediments (middle Miocene to lower Pleistocene) of Arunachal Pradesh, eastern Himalaya: Systematic and palaeoclimatic implications; Rev. Palaeobot. Palynol. 214 9-26.

Khan M A, Spicer R A, Spicer T E V and Bera S 2016 Occurrence of Shorea Roxburgh ex C. F. Gaertner (Dipterocarpaceae) in the Neogene Siwalik forests of eastern Himalaya and its biogeography during the Cenozoic of southeast Asia; Rev. Palaeobot. Palynol. 233 $236-254$.

Khan M A, Spicer R A, Spicer T E V and Bera S 2017 Evidence for diversification of Calophyllum L. (Calophyllaceae) in the Neogene Siwalik forests of eastern Himalaya; Plant Syst. Evol. 303 371-386.

Kumar G 1997 Geology of Arunachal Pradesh (Bangalore: Geol. Soc. India).

Kramer K 1974 Die Tertiären Hölzer südost-Asiens (unter ausschluss der Dipterocarpaceae). Part 2. Palaeontogr. 145B 1-150.

Kräusel R 1939 Ergebnisse der Forschungsreisen Prof. E. Stromers in den Wüsten Ägyptens. IV. Die fossilen Floren Ägyptens; Abh. Bayer. Akad. Wiss. 47 1-140.

Kribs D A 1959 Commercial foreign woods on the American market (Pennsylvania: Pennsylvania State University).

Lacey W S 1963 Palaeobotany technique; In: Viewpoint in Biology (eds) Carthey J D and Duddington I (London: Butterworths) 2 202-243.

Lakhanpal R N and Awasthi N 1965 Fossil woods of Calophyllum from the Tertiary of south India; Palaeobotanist 13 328-336.

Lalitha C and Prakash U 1980 Fossil wood of Sindora from the Tertiary of Assam with a critical analysis of anatomically allied forms; Geophytol. 10 174-187.

Lemoigne Y and Beauchamp J 1973 Paléoflores tertiares de la région de Welkite (Ethiopie, province du Shoa); Bull. Soc. Geol. France Ye Serie 14 336-352.

Licht A, Boura A, De Franceschi D, Ducrocq S, Aung Naing Soe and Jaeger J-J 2014 Fossil woods from the late middle Eocene Pondaung Formation, Myanmar; Rev. Palaeobot. Palynol. 202 29-49.

Licht A, Boura A, De Franceschi D, Utesher T, Sein C and Jaeger J-J 2015 Late middle Eocene fossil wood of Myanmar: Implications for the landscape and the climate of the Eocene Bengal Bay; Rev. Palaeobot. Palynol. 216 $44-54$.

Louvet P 1975 Sur trois bois fossiles du Tertiarie de Libye; Bull. Soc. Bot. France $121269-280$.

Mabberley D J 1997 The plant book: A portable dictionary of vascular plants (Cambridge: Cambridge University Press).

Mehrotra R C, Prakash U and Bande M B 1984 Fossil wood of Lophopetalum and Artocarpus from the Deccan Intertrappean beds of Mandla District, Madhya Pradesh, India; Palaeobotanist 32 310-320.
Mehrotra R C, Awasthi N and Dutta S K 1999 Study of fossil wood from the upper Tertiary sediments (Siwalik) of Arunachal Pradesh, India and its implication in palaeoecological and phytogeographical interpretations; Rev. Palaeobot. Palynol. 107 223-247.

Mehrotra R C, Liu Xiu-Qun, Li Cheng-Sen, Wang Yu-Fei and Chauhan M S 2005 Comparison of the Tertiary flora of southwest China and northeast India and its significance in the antiquity of the modern Himalayan flora; Rev. Palaeobot. Palynol. 135 145-163.

Mehrotra R C, Bera S K, Basumatary S K and Srivastava G 2011 Study of fossil wood from the Middle-Late Miocene sediments of Dhemaji and Lakhimpur districts of Assam, India and its palaeoecological and palaeophytogeographical implications; J. Earth Syst. Sci. 120 681-701.

Mehrotra R C, Tiwari R P, Srivastava G and Shukla A 2013 Further contribution to the Neogene petrified wood forest of Mizoram, India; Chinese Sci. Bull. 58 (Suppl. 1) 104110.

Mehrotra R C, Srivastava Gaurav and Basumatary S K 2016 Fossil woods from the late Miocene-Pliocene sediments of Arunachal Pradesh; Geophytol. 46 163-172.

Metcalfe C R and Chalk L 1950 Anatomy of the dicotyledons 1 and 2 (Oxford: Clarendon Press).

Miles A 1978 Photomicrographs of world woods (London: Building Research Establishment Report).

Mukherjee D and Prasad M 2013 An ebenaceous wood from the Neyveli lignite, South Arcot District, Tamil Nadu, India; Geophytol. 42 127-133.

Müller-Stoll W R and Mädel-Angeliewa E 1967 Die fossilen Leguminosen hölzer, revision der mit Leguminosen verglichenen fossilen hölzer und beschreibungen älterer und neurer Arten; Palaeontogr. 119B 95-174.

Müller-Stoll W R and Mädel-Angeliewa E 1986 Ein neues Guttifern-Holz aus dem Tertiär von Java, Calophylloxylon intermedium sp. nov; Feddes Repert. 97 225-233.

Navale G K B 1963 Fossil woods of Leguminosae from Tertiary rocks of the Cuddalore Series near Pondicherry, India; Palaeobotanist 11 54-65.

Nigam P N 1963 Family Celastraceae; In: Indian Woods 2 (ed.) Anonymous (Delhi: The Manager of Publications), pp. 180-194.

Normand D 1950 Atlas de Bois de la Cote d'Ivoire, 1 (Nogent-sur-Marne: Centre Technique for Tropical Forestier).

Pearson R S and Brown H P 1932 Commercial Timbers of India 1 and 2 (Calcutta: Government of India Central Publication Branch).

Pilgrim G E 1910 Preliminary note on a revised classification of the Tertiary fresh water deposits of India; Rec. Geol. Surv. India 40 185-205.

Poole I 2000 Fossil angiosperm wood: Its role in the reconstruction of biodiversity and palaeoenvironment; Bot. J. Linn. Soc. 134 361-381.

Prakash U 1966a Some fossil dicotyledonous woods from the Tertiary of eastern India; Palaeobotanist 14 $223-235$.

Prakash U 1966b Pahudioxylon deomaliense sp. nov., a new fossil wood from the Tertiary of eastern India; Curr. Sci. 34 433-434.

Prakash U 1978 Fossil woods from the lower Siwalik beds of Uttar Pradesh, India; Palaeobotanist 25 376-392. 
Prakash U 1979 Some more fossil woods from the Lower Siwalik beds of Himachal Pradesh, India; Him. Geol. 8 61-81.

Prakash U 1981 Further occurrence of fossil woods from the Lower Siwalik beds of Uttar Pradesh, India; Palaeobotanist 28-29 374-388.

Prakash U and Tripathi P P 1970 Fossil woods from the Tipam Sandstones near Hailakandi, Assam; Palaeobotanist 18 183-191.

Prakash U and Tripathi P P 1975 Fossil dicotyledonous woods from the Tertiary of eastern India; Palaeobotanist 22 51-62.

Prakash U, Boureau E and Louvet P 1967 Les plans ligneux convergents et la nomenclature de bois de Legumineuses Tertiaires du Sahara et d'Asie; Taxon 16 505-509.

Prakash U, Mishra V P and Srivastava G P 1988 Fossil wood resembling Sindora from the Tertiary of Palamau District, Bihar; Rec. Geol. Surv. India 118 69-73.

Prakash U, Lalitha V and Tripathi P P 1994 Plant remains from the Tipam sandstones of northeast India with remarks on the palaeoecology of the region during the Miocene; Palaeontogr. 231B 113-146.

Prasad M 1989 Some more fossil woods from the lower Siwalik sediments of Kalagarh, Uttar Pradesh; Geophytol. 18 135-144.

Prasad M 1993 Siwalik (Middle Miocene) woods from the Kalagarh area in the Himalayan foothills and their bearing on palaeoclimate and phytogeography; Rev. Palaeobot. Palynol. 76 49-82.

Prasad M 2006 Plant fossils from Siwalik sediments of Himachal Pradesh and their palaeoclimatic significance; Phytomorphol. 56 9-22.

Prasad M 2008 Angiospermous fossil leaves from the Siwalik foreland basins and their palaeoclimatic implications; Palaeobotanist 57 177-215.

Prive-Gill C, Thomas H and Lebret P 1999 Fossil wood of Sindora (Leguminosae, Caesalpiniaceae) from the OligoMiocene of Saudi Arabia: Paleobiogeographical considerations; Rev. Palaeobot. Palynol. 107 191-199.

Raju D S N and Misra R 2009 Proterozoic and Phanerozoic integrated stratigraphy of south-east Asia (India, Pakistan, Bangladesh, Myanmar and Sri Lanka); In: $O N G C$ Bulletin (eds) Raju D S N and Misra R (Dehradun: KDMIPE) 44(2) 203-236.

Ranga Rao A, Aggarwal R P, Sharma U N, Bhalla M S and Nanda A C 1988 Magnetic polarity stratigraphy and vertebrate palaeontology of the Upper Siwalik Subgroup of Jammu Hills, India; J. Geol. Soc. India 31 361-385.

Ramesh Rao K, Purkayastha S K, Shahi R, Juneja K B S, Negi B S and Kazmi H M 1972 Family Leguminosae; In: Indian Woods (eds) Ramesh Rao K and Purkayastha S K (Delhi: The Manager of Publications) 3 264-323.

Ridley H N 1967 The flora of Malaya Peninsula, 1 (Amsterdam: Asher).

Salard-Cheboldaeff M, Dupéron-Laudoueneix $M$ and Dupéron J 2012 Bois minéralisés cénozoïques de Nouvelle-Calédonie; Palaeontogr. 288B 65-97.

Selmeier A 1976 Zwei verkieselte Diospyros-Hölzer aus tertiaren Schichten Sud-Bayerns; Naturw. Z. Niederbayern 26 20-46.

Shashi, Pandey S M and Tripathi P P 2006 Fossil leaf impressions from Siwalik sediments of Himalayan foot hills of
Uttaranchal, India and their significance; Palaeobotanist 55 77-87.

Shashi, Pandey S M and Tripathi P P 2008 Siwalik (Middle Miocene) leaf impressions from Tanakpur area, Uttaranchal and their bearing on climate; Geophytol. 37 99108.

Singh T and Prakash U 1980 Leaf-impressions from the Siwalik sediments of Arunachal Pradesh; Geophytol. 10 104-107.

Spicer R A, Bera S, De Bera S, Spicer T E V, Srivastava G, Mehrotra R, Mehrotra N and Yang J 2011 Why do foliar physiognomic climate estimates sometimes differ from those observed? Insights from taphonomic information loss and a CLAMP case study from the Ganges Delta; Palaeogeogr. Palaeoclimatol. Palaeoecol. 302 381-395.

Srivastava G and Mehrotra R C 2013 Endemism due to climate change: Evidence from Poeciloneuron Bedd. (Clusiaceae) leaf fossil from Assam, India; J. Earth Syst. Sci. 122 283-288.

Srivastava G, Mehrotra R C and Tiwari R P 2009 Fossil wood from the Tipam Group of North Hlimen, Mizoram; Palaeobotanist 58 29-32.

Srivastava G, Spicer R A, Spicer T E V, Yang J, Kumar M, Mehrotra R and Mehrotra N 2012 Megaflora and palaeoclimate of a Late Oligocene tropical delta, Makum Coalfield, Assam: Evidence for the early development of the south Asia monsoon; Palaeogeogr. Palaeoclimatol. Palaeoecol. 342-343 130-142.

Srivastava G, Mehrotra R C, Shukla A and Tiwari R P 2014 Miocene vegetation and climate in extra peninsular India: Megafossil evidences; Palaeontol. Soc. India Spec. Publ. No. 5 283-290.

Srivastava G, Gaur R and Mehrotra R C 2015 Lagerstroemia L. from the middle Miocene Siwalik deposits, northern India: Implication for Cenozoic range shifts of the genus and the family Lythraceae; J. Earth Syst. Sci. 24 227239.

Srivastava R and Mehrotra R C 2009 Plant fossils from Dafla Formation, West Kameng District, Arunachal Pradesh; Palaeobotanist 58 33-49.

Tandon K N and Purkayastha S K 1958 Family Guttiferae; In: Indian Woods $\mathbf{1}$ (eds) Chowdhury K A and Ghosh S S (Delhi: The Manager of Publications), pp. 69-85.

Tandon S K 1991 The Himalayan Foreland: Focus on Siwalik Basin; In: Sedimentary Basins of India: Tectonic Context (eds) Tandon S K, Pant C C and Casshyap S M (Nainital: Gyanodaya Prakashan), pp. 177-201.

Tiwari R P, Mehrotra R C, Srivastava Gaurav and Shukla Anumeha 2012 The vegetation and climate of a Neogene petrified wood forest of Mizoram, India; J. Asian Earth Sci. 61 143-165.

Trivedi B S and Srivastava R 1982 A fossil wood of Ebenaceae from the Deccan Intertrappean beds of Madhya Pradesh (India); J. Indian Bot. Soc. 61 254-259.

Valdiya K S 2002 Emergence and evolution of Himalaya: Reconstructing history in the light of recent studies; Prog. Phys. Geogr. 26 360-399.

Vozenin-Serra C 1981 Les structures ligneuses Neogens du plateau de Di Linh (Sud-Vietnam); Palaeontogr. 177B $136-161$.

Wiemann M C, Wheeler E A, Manchester S R and Portier K M 1998 Dicotyledonous wood anatomical characters 
as predictors of climate; Palaeogeogr. Palaeoclimatol. Palaeoecol. 139 83-100.

Wheeler E A and Baas P 1991 A survey of the fossil record for dicotyledonous wood and its significance for evolutionary and ecological wood anatomy; IAWA Bull. New Ser. 13 $275-332$.

Wheeler E A and Baas P 1993 The potentials and limitations of dicotyledonous wood anatomy for climatic reconstructions; Paleobiol. 19 487-498.

Wheeler E A, Pearson R G, La Pasha C A, Zack T and Hatley W 1986 Computer aided wood identification; North Carolina Agr. Res. Service Bull. 474 1-96.

Willis J C 1973 A dictionary of flowering plants and ferns (Cambridge: Cambridge University Press).

Corresponding editor: Pratul K Saraswati
Wolfe J A 1979 Temperature parameters of humid to mesic forests of eastern Asia and relation to forests of other regions of the Northern Hemisphere and Australasia; U.S. Geol. Surv. Prof. Paper 1106 1-37.

Wolfe J A and Upchurch Jr G R 1987 North American nonmarine climates and vegetation during the Late Cretaceous; Palaeogeogr. Palaeoclimatol. Palaeoecol. 61 33-77.

Woodcock D W and Ignas C M 1994 Prevalence of wood characters in eastern North America: What characters are most promising for interpreting climates from fossil wood; Am. J. Bot. 81 1243-1251.

Woodward F I, Lomas M R and Kelly C K 2004 Global climate and the distribution of plant biomes; Proc. Roy. Soc. London B 359 1465-1476. 